\title{
Imprints of volcanic, erosional, depositional, tectonic and mass-wasting processes in the morphology of Santa Maria insular shelf (Azores)
}

DOI:

10.1016/j.margeo.2020.106163

\section{Document Version}

Accepted author manuscript

Link to publication record in Manchester Research Explorer

Citation for published version (APA):

Ricchi, A., Quartau, R., Ramalho, R. S., Romagnoli, C., Casalbore, D., \& Zhao, Z. (2020). Imprints of volcanic, erosional, depositional, tectonic and mass-wasting processes in the morphology of Santa Maria insular shelf (Azores). Marine Geology, 424. https://doi.org/10.1016/j.margeo.2020.106163

\section{Published in:}

Marine Geology

\section{Citing this paper}

Please note that where the full-text provided on Manchester Research Explorer is the Author Accepted Manuscript or Proof version this may differ from the final Published version. If citing, it is advised that you check and use the publisher's definitive version.

\section{General rights}

Copyright and moral rights for the publications made accessible in the Research Explorer are retained by the authors and/or other copyright owners and it is a condition of accessing publications that users recognise and abide by the legal requirements associated with these rights.

\section{Takedown policy}

If you believe that this document breaches copyright please refer to the University of Manchester's Takedown Procedures [http://man.ac.uk/04Y6Bo] or contact uml.scholarlycommunications@manchester.ac.uk providing relevant details, so we can investigate your claim.

\section{OPEN ACCESS}


Title: Imprints of volcanic, erosional, depositional, tectonic and mass-wasting processes in the morphology of Santa Maria insular shelf.

Alessandro Ricchia , Rui Quartau ${ }^{b, c}$, Ricardo S. Ramalhoc,d,e,f, Claudia Romagnolia, Daniele Casalboreg,h, Zhongwei Zhao ${ }^{i}$

aUniversity of Bologna, Dip. Scienze Biologiche, Geologiche e Ambientali, Bologna, Italy bInstituto Hidrográfico, Divisão de Geologia Marinha, Lisboa, Portugal 'Instituto Dom Luiz, Faculdade de Ciências, Universidade de Lisboa, Lisboa, Portugal dDepartamento de Geologia, Faculdade de Ciências, Universidade de Lisboa, Lisboa, Portugal eSchool of Earth Sciences, University of Bristol, Bristol, UK 'Lamont-Doherty Earth Observatory at Columbia University, Palisades, NY, USA glstituto di Geologia Ambientale e Geoingegneria, Consiglio Nazionale delle Ricerche, Area della Ricerca, Roma, Italy hSapienza Università di Roma, Dipartimento Scienze della Terra, Roma, Italy 'Department of Earth and Environmental Sciences, University of Manchester, Williamson Building, Oxford Road, Manchester M13 9PL, UK.

Corresponding author: Rui Quartau (rui.quartau@hidrografico.pt)

Highlights: (85 characters)

- The wider northern shelf suggests that the island might be older than $6 \mathrm{Ma}$

- The shelf is mostly sediment-deprived, except in fault-controlled basins

- Depositional sequences in island shelves are hard to preserve due to wave exposure

- Mass wasting at the shelf edge is driven by tectonics and sediment accumulation 


\section{Abstract}

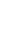

The present-day morphology of volcanic island shelves is the result of several factors, namely the original shape and structure of the volcanic edifice, the nature and age of the materials that compose its flanks, and the erosional, volcanic, tectonic and sedimentary processes that acted to form these shelves. By combining detailed seafloor mapping with onshore studies it is possible to gain a unique insight onto the evolution of volcanic island edifices and the processes that helped to shape their shelves. Here we look at Santa Maria Island in the Azores Archipelago, which is a 6 Ma old ocean-island volcano surrounded by a $135 \mathrm{~km}^{2}$ shelf, characterized by an history of subsidence since its formation c. $6 \mathrm{Ma}$ ago, followed by uplift from 3.5 Ma onwards. By analyzing the geomorphic parameters of the insular shelf (such as the shelf width and the erosive edge depth), the island's history of vertical movements, and by relating the morphology of the outcrops found on the shelf with those onshore, we contribute to a better knowledge of the evolutionary history of Santa Maria with particular focus on its earlier stages of growth. We infer that the outer part of the northern shelf is carved on units older than the oldest volcanic sequences exposed on land; the western and southern shelves are almost entirely carved in the products of the oldest shield volcano (Anjos Volcanic Complex), whilst the eastern shelf is the youngest in formation, being related to units of the Pico Alto volcanic complex. We also discuss the distribution of sediments on the shelf. High wave energy concomitant with sea level drops contributed to the erosion and transport of older sequences offshore, which were ultimately lost to the slopes of the island, resulting in a shelf that is sediment-stripped for the most part. Presently, wide shelves further contribute to wave-energy dissipation, resulting in a significantly diminished sediment production. The shelf edges around Santa Maria exhibit several erosive scars, interpreted as the head of a submarine drainage network carved on the slopes of the island. On the western, 
25 southern and eastern shelves, these mass-wasting features are mostly controlled by tectonics 26 since the extension of faults and lineaments can be followed from onshore to the shelf edge. On 27 the northern shelf mass-wasting appears to be mostly correlated with presence of unstable 28 sediments on the shelf edge that triggered landsliding. Overall, this work shows how detailed 29 mapping of the shelves surrounding old volcanic islands can still provide important 30 complementary information about the evolution of these islands, which could not be acquired 31 solely by the study of their subaerial and deeper submarine parts. 


\section{1. Introduction}

The subaerial and submarine morphology of volcanic islands results from the interplay between volcanic, tectonic, erosive and depositional processes acting at different time-scales (Ramalho et al., 2013; Casalbore et al., 2015; Lebas et al., 2018; Quartau et al., 2018a). These processes and their influence on the geomorphology are very well known for the subaerial portions of volcanic islands (e.g., Thouret, 1999). However, volcanic islands are mostly developed beneath the sea; hence the study of their submarine areas can provide much more information than the subaerial parts, which constitute only the "tip of iceberg" (e.g., Quartau and Mitchell, 2013; Quartau et al., 2015a). Most part of submarine studies was mainly addressed to reconstruct large-scale instability processes that commonly affect the flanks of these edifices (Moore et al., 1989; Deplus et al., 2001; Masson et al., 2002; Mitchell et al., 2002; Oehler et al., 2008; Casalbore et al., 2011; Montanaro and Beget, 2011). On the contrary, less attention has been paid on the impact of volcanism, erosion, tectonics, time-variant sediment supply and climatic/oceanographic conditions on the surrounding shelves and the link with the geology onshore. Only in the last decade, a few number of nearshore marine surveys performed with high-resolution multibeam and seismic reflection systems revealed the importance of insular shelf studies to obtain a more detailed picture of the geological history of volcanic islands (Quartau et al., 2012; Romagnoli, 2013; Quartau et al., 2014; Quartau et al., 2015b; 2016; Casalbore et al., 2018; Ricchi et al., 2018; Romagnoli et al., 2018). Insular shelves surrounding volcanic islands are, in fact, representative of their original subaerial extension during glacial maxima, thus playing a potential role for palaeomorphological and relative age reconstructions as well as for evaluating the vertical mobility of such areas (Lucchi et al., 2019; Quartau et al., 2016, 2018b; Ricchi et al., 2018). Geomorphic parameters such as the shelf edge depth and shelf width, as well as the morphology of the submerged lava flows or rocky outcrops, provide useful insights concerning the original 
morphology of the volcanic edifices, and the occurrence of (older or younger than expected) volcanic activity not recorded onshore (Quartau et al., 2014; 2015b; Ramalho et al., in press; Romagnoli et al, 2018). For instance, shelf width can be related with shelf age (beginning of incision) and as such may be used to infer reveal relative ages of undated coastal sectors (Quartau et al., 2010; Romagnoli et al, 2018). In a similar fashion, coastal sectors formed by volcanism with similar ages but different orientations to waves generally exhibit different shelf widths and may thus reveal that wave regimes have probably not changed through time (Llanes et al., 2009; Mitchell et al, 2003; Quartau et al., 2010). Erosional shelf breaks which are now deeper than the lowest sea-level stands, may also be related with subsidence of the volcanic edifices and thus rates of vertical movements can also be estimated from the depth of the shelf break (Lucchi et al., 2019; Quartau et al., 2014, 2016, 2018b), in a similar way that constructional slopes breaks were used in Hawaii to estimate subsidence and relative age constraints of volcanic edifices (Taylor, 2019). To date, however, only a few studies have discussed sediment deposition on volcanic island shelves and the preservation of their depositional sequences (Ávila et al., 2008; Casalbore et al., 2018; Meireles, 2013; Quartau et al., 2012). Moreover, all the existing shelf studies have focused on relatively young islands ( $1 \mathrm{Ma}$ or less). At Santa Maria, however, there there is the opportunity of looking into a much older island ( $6 \mathrm{Ma})$ and test whether the approaches and interpretation taken from younger islands could also apply to older edifices. In addition, Santa Maria's shelf is up to now, one of the best surveyed insular shelves in the world, with a cover of multibeam bathymetry of $1 \mathrm{~m}$ resolution and a grid of high-resolution seismic profiles not spaced more than $250 \mathrm{~m}$. This opportunity provides a unique and more detailed, careful analysis on the factors that impact shelf evolution and sedimentary dynamics in an energetic environment such as the Azores. In this study, we combined high-resolution geophysical dataset with detailed onshore geological field studies performed on Santa Maria Island (Azores Archipelago) to better 
understand the connection between the onshore and the offshore domain. This allows unprecedented inferences on the contribution of tectonics, wave regime, volcanism, erosion and sediment supply in shaping the insular shelf. Moreover, through the analysis and comparison of the shelf width, shelf edge depth and morphology for each sector of the island, a better understanding of the evolution of Santa Maria is derived.

\section{Geological setting}

\subsection{The Azores Archipelago}

The Azores Archipelago is located in the North Atlantic Ocean, on both sides of the Mid-Atlantic Ridge (MAR in Fig. 1), which separates the westernmost group of islands from the central and easternmost groups. Volcanism here possibly results from the interaction between the triple junction of the Eurasian, Nubian and American lithospheric plates and a hotspot (Gente et al., 2003). The complex interaction between the seafloor spreading forces driven by the Mid Atlantic Ridge and the right-transtensional movements associated with the Nubian/Eurasian plate's boundary dominates the area (Lourenço et al., 1998; Hipólito et al., 2013; Marques et al., 2013; Madeira et al., 2015). Santa Maria sits at the SE corner of a roughly triangular shaped area located between the Nubian/European plate boundary (the active Terceira Rift, TR in Fig. 1) and the presently inactive East Azores Fracture Zone (EAFZ in Fig. 1), most likely already outside the influence of the Nubian/European plate boundary (Miranda et al., 2018).

Being under an oceanic regime, the coastlines of the Azores Archipelago are frequently subjected to high wave energy. The North Atlantic Oscillation and Eastern Atlantic atmospheric circulation bring extreme storms (wave heights exceeding $16 \mathrm{~m}$ and peak periods exceeding $18 \mathrm{~s}$ ) affecting the Azores at least once every seven years (Andrade et al., 2008; Zhao et al., 2019). For instance, 
the recent Hurricane Lorenzo impacted the Azores in October 2019, with wave heights yielding 15 $m$ that violently destroyed the port of Lajes on Flores Island, western Azores (Hatton, 2019).

\subsection{Geology of Santa Maria Island}

Santa Maria Island rises from the seafloor at around $-2500 \mathrm{~m}$ and it is considered the oldest island of the Azores Archipelago, since it emerged from the sea c. 6 Ma ago (Ramalho et al., 2017). The eastern (leeward) side of the island exhibits a rugged morphology, culminating in the Pico Alto high (587 m in elevation, Fig. 2). In this sector, the coastline is made of up to $250-300 \mathrm{~m}$ high plunging cliffs, occasionally displaying wave-cut notches at varying elevations. On the contrary, the western (windward) side has a typical staircase morphology due to the occurrence of a number of raised marine terraces from $7 \mathrm{~m}$ to $200 \mathrm{~m}$ in elevation, some of which still exhibit remains of coastal sediments (Ramalho et al., 2017). Offshore, Santa Maria is surrounded by a wide insular shelf, in particular along the northern coastal sector (up to $8 \mathrm{~km}$ wide), in contrasts with narrower shelves at the western, southern and eastern sides $(\sim 2 \mathrm{~km})$. Five sets of submerged marine terraces have been recognized on the shelf, reflecting the interplay between the island's vertical movements and sea-level fluctuations (Ricchi et al., 2018).

The volcanic history of Santa Maria is the result of the activity of different overlapping volcanoes, interrupted by relative long periods of quiescence and erosion (Serralheiro et al., 1987; Serralheiro and Madeira, 1993; Ramalho et al., 2017). The volcanism of the Cabrestantes and Porto Formations on the westernmost side of the island (Fig. 2), emplaced by surtseyan and strombolian activity, witnesses the first emergence of the island and transition to a subaerial volcanic edifice c. 6 Ma ago. The products of the Anjos Volcanic Complex are widespread in the central and western portions of the island, representing the remnants of a large shield volcano formed between 5.8 Ma and 5.3 Ma (Fig. 2) (Sibrant et al., 2015; Ramalho et al., 2017). The 
following 1 Ma was mostly characterized by marine erosion that caused the partial dismantling, and possibly submersion of the previously formed shield volcano. A collapse of the eastern flank of the Anjos volcanic edifice has also been proposed by Sibrant et al (2015). Simultaneously with marine sedimentation on top of the eroded volcano, which probably constituted a wide shoal with some residual subaerial reliefs, low-volume submarine volcanism took place, mainly focused on the eastern portion of the island (Ramalho et al., 2017). This culminated in the emplacement of the Touril Volcano-sedimentary Complex between 5.3 Ma and 4.1 Ma (Fig. 2). During this period the island experienced a subsidence trend (c. $100 \mathrm{~m} / \mathrm{Myr}$ on average) that lasted until $3.5 \mathrm{Ma}$ as attested by the numerous passage zones of Pico Alto and Anjos lava deltas (which indicate increasingly higher relative paleo sea levels towards the top of the sequence) and the transgressive sequences of Touril complex showing a deepening-up sequence (Ramalho et al., 2017). Widespread volcanic activity resumed c. $4.1 \mathrm{Ma}$, promoting the re-emergence of the island edifice. The products of the Pico Alto volcanic complex (Fig. 2) correspond to the lateral growth of the edifice due to lava delta progradation over the Touril marine sediments and the eroded remains of the Anjos edifice. Subsidence reversed into uplift at $3.5 \mathrm{Ma}$ (estimated at c. $59 \mathrm{~m} / \mathrm{Myr}$ from 3.5 Ma to 2.14 Ma and 42 m/Myr from 2.14 Ma to present), as attested by the position of the passage zone of Pico Alto's lava deltas (up to $200 \mathrm{~m}$ ), and the occurrence of marine terraces on the western side of the island and offshore (Ramalho et al., 2017; Ricchi et al., 2018). Although the last stage of the island evolution is considered mainly erosional, from 3.2 to $2.8 \mathrm{Ma}$ a low volume of magmatic and hydromagmatic activity led to the formation of the cones and products of the last post-erosional phase, roughly corresponding to the Feteiras Formation of Serralheiro et al. (1987) or the Young Parasitic Cones of Sibrant et al. (2015) (Fig. 2).

Tectonics is expressed onshore by the main NW-SE, N-S and NE-SW-trending faults (Fig. 2, Madeira et al., 2015) that partly influenced the development of the subaerial terraces and 
submerged terraces on the shelf (Ricchi et al., 2018). Moreover, Zbyszewski and Ferreira (1960) and Serralheiro et al. (1987) reported a large set of $\mathrm{N} 045^{\circ}$ and $\mathrm{N} 150^{\circ}$ striking dikes located mostly in the SW and NE portion of the island (Fig. 2), being likely contemporaneous to the main building stages of the island.

Santa Maria is the driest island in the Azores, with the low western half exhibiting between 670 and $800 \mathrm{~mm} /$ year of precipitation and the more rugged and taller eastern side reaching higher values, between 1100-1700 mm/year (Fernandes, 2004).

\subsection{Sedimentary dynamics at reefless Volcanic Ocean Islands}

On reefless volcanic islands the production of sediments reaching the coast largely depends on volcanic activity (for instance explosive volcanism produces much more clastic materials than effusive volcanism), the occurrence of a well-developed subaerial drainage system, wet climate stimulating the subaerial erosion, and high wave energy promoting coastal erosion and sediment redistribution (Krastel et al., 2001; Ramalho et al., 2013; Quartau et al., 2018a). In particular, on small and relatively dry reefless volcanic islands (like Santa Maria), sediment is produced mainly through the erosion of coastal cliffs by wave processes because rivers do not have enough area to develop and the low precipitation imprints a weak fluvial erosion regime (Quartau et al., 2012). Thus, on these islands, sediments that result from cliff erosion accumulate in the inner shelf and are partly transported offshore during storms. Several studies showed, in fact, that storms are able to produce storm-induced downwelling currents that transport sediments from shallow to deeper areas of the shelf (Field and Roy, 1984; Tsutsui et al., 1987; Hernández-Molina et al., 2000; Chiocci and Romagnoli, 2004; Meireles et al., 2013). These sediments tend to form clinoform deposits, as recognized on other volcanic islands of the Azores (Quartau et al., 2012; 2014; 2015b) and in the 
Mediterranean Sea (where they are named "submerged or submarine depositional terraces", Chiocci and Romagnoli, 2004; Casalbore et al., 2017; Romagnoli et al., 2020).

\section{Material and methods}

\subsection{Shelf data acquisition and processing}

The shelf around Santa Maria Island has been surveyed onboard the R/V Arquipélago from $24^{\text {th }}$ August to $15^{\text {th }}$ September 2016 in the scope of PLATMAR project. The survey (PLATMAR 1/2016) included the acquisition of multibeam bathymetry and single-channel seismic profiles (boomer) between c. $-20 \mathrm{~m}$ and c. $-250 \mathrm{~m}$ (Figs. 3 and 4). Further details of the geometry acquisition and equipment were reported by Ricchi et al. (2018). The subaerial DTM was generated from a 1/5000 scale digital altimetric database with a resolution of $5 \mathrm{~m}$. An integrated analysis of the multibeam bathymetry and subaerial topography has been mainly used to study the morphology of the shelf by mapping the volcanic, structural, erosional and depositional features and comparing with those of the corresponding onshore sectors (Figs. 4, 5a, 6a, 7a, 8a and 1ESM). The shelf width and the erosive edge depth values in each sector were determined from the seismic profiles collected perpendicular to the coastlines (Fig. 3) and reported in graphs in order to constrain its variability along the shelf (Figs. 5a, 6a, 7a and 8a). The erosive shelf edge was defined as the point, in the rocky basement of the seismic profiles, where there is a significant increase in gradients to the slope of the island (e.g., Fig. 2ESM). Shelf width was only measured where erosive shelf edge and coastlines stretches were roughly parallel to each other, whilst shelf edge depth was measured along the entire shelf. Since mass wasting of the shelf edge can cause a landward shift of that feature and shallow its depth, we always took into account in our interpretation areas without scars, which is considered to represent the original depth at which waves cut the island subaerial 
flanks. The analysis of seismic reflection profiles allowed mapping the distribution and thickness of the unconsolidated sediments lying on the shelf of Santa Maria Island (Fig. 9 and Table 1). In each seismic profile we picked two reflectors corresponding to the seafloor and, where present, the bottom of the sedimentary cover, respectively. For time/depth conversion we used a sound velocity of $1500 \mathrm{~m} / \mathrm{s}$ for the water column and $1800 \mathrm{~m} / \mathrm{s}$ for the sediments. Sound velocity is based on data of Hamilton and Bachman (1982) for coarse sands, which in the Azorean shelves are the dominant grain-size (Quartau et al., 2012; Quartau et al., 2015b).

\subsection{Wave regime characterization}

Using the model outputs of the European Centre for Medium range Weather Forecasts (ECMWF) 40-yr Re-Analysis (ERA-40) (Uppala et al., 2005) and ECMWF Interim Re-Analysis (ERAInterim) (Dee et al., 2011), a rose diagram for Santa Maria offshore significant wave heights (and their associated percentages and originating directions was produced (Figure 10, Table 1ESM). These wave properties were extracted from a six hourly significant wave height $\mathrm{H}_{\mathrm{s}}$ database and averaged for the sea area adjacent to Santa Maria Island $\left(36.875^{\circ} \mathrm{N}-37.125^{\circ} \mathrm{N}, 24.9375^{\circ} \mathrm{W}-\right.$ $25.25^{\circ} \mathrm{W}$ ) for the period September 1957 to August 2019 and represent the base for discussing the the wave regime in the different shelf sectors.

\section{Results}

\subsection{Morphology of the insular shelf around Santa Maria Island}

\subsubsection{Northern shelf sector}

This sector is located offshore the northern coast of the island from Baía do Mar da Barca to Ponta do Norte (A to B in Fig. 5a). The roughly ENE-WSW oriented coastline has a strongly irregular 
profile characterized by embayments and promontories. From Ponta do Norte to Ponta dos

194

Frades, sea cliffs are steep, up to $200 \mathrm{~m}$ high, and were cut in the products of the Anjos Volcanic Complex at the base, overlapped by those of Touril Volcano-sedimentary and Pico Alto Volcanic Complex (see Fig. 2), forming a tabular sequence, dipping very gently to the eastern quadrant. From Ponta dos Frades to Baía do Mar da Barca, cliffs are entirely carved in the products of the Anjos Volcanic Complex and their height progressively decreases westwards to $\sim 20-30 \mathrm{~m}$. The entire shelf has a roughly trapezoidal shape and shows a different morphology between the eastern and the western sides, similarly to the asymmetric topography of the island. To the east of Ponta dos Frades the shelf width varies between $6 \mathrm{~km}$ and $8 \mathrm{~km}$, while to west is narrower being c. $4 \mathrm{~km}$ wide (not considering the sector where the submarine cone of Baixa do Ambrósio is located, Figs. $5 a$ and $5 b)$. The maximum depth of the erosive shelf edge is $c .170 \mathrm{~m}$ on the northwestern portion (off Baía do Mar da Barca, Figs. 5a and profile aa' in Fig. 2ESM), then it slowly decreases to $156 \mathrm{~m}$ to the north and increases again up to $172 \mathrm{~m}$ in the northeast. Depth values as low as c. 115 $m$ can be found, corresponding to scars affecting the shelf edge.

To the west of Ponta dos Frades, rocky outcrops have been recognized down to a depth of 80$100 \mathrm{~m}$, being mostly located in the inner to middle shelf. These are cut by sharp linear escarpments, ranging in heights from c.10 m to c.30 m in three compartmented blocks (Fig. 5a). These lineaments, 2 to $2.7 \mathrm{~km}$ long, can be followed from the subaerial island into shallow water and down to $-100 \mathrm{~m}$, where they apparently disappear in an area characterized by an overall smooth morphology. Offshore continuation of these lineaments is possibly represented by a sharp escarpment that dissects a rocky outcrop located to the south of Baixa do Ambrósio at c.-130/-170 m (probable extension of AjF in Fig. 5a) and by a narrow gully head, located SE of Baixa do Ambrósio at -135 m (probable extension of CF in Fig. 5a). To the east, another lineament (RF in Fig. 5a) can be also apparently followed offshore in a NNW-SSE linear escarpment c. 2 km long, down 
217 to $-50 \mathrm{~m}$. These major lineaments are in clear connection with recognized fault 218 planes/escarpments on land, as they are more evident in the case of the Aeroporto and Anjos 219 Faults (AF and AjF in Fig. 5a and profile $\mathrm{CC}^{\prime}$ in Fig. 3ESM).

220 To the east of Ponta dos Frades, the entire shelf is dominated by rocky outcrops with some sub221 conical or elongated morphological highs. A total of 26 sub-conical structures were recognized 222 from c. $-70 \mathrm{~m}$ to c. $-120 \mathrm{~m}$ on this shelf sector (Fig. 5a). These morphological features show a 223 random arrangement on the shelf and exhibit different sizes and morphologies. Four types of subconical landforms were identified in this sector: a) small conical, circular or elongated, positive relief (numbers 1-9 in Fig. 5a); b) larger, more irregular and concentric morphologies with positive relief and sometimes a flat or depressed top, and with a basal diameter from c. $0.25 \mathrm{~km}$ to c. $1 \mathrm{~km}$ and heights comprehended between c. $20 \mathrm{~m}$ and c. $40 \mathrm{~m}$ (numbers 10-18 in Fig. 5a); c) large roughly-circular features with a wide central depression, ranging from $800 \mathrm{~m}$ to $1.2 \mathrm{~km}$ in width and up to $30 \mathrm{~m}$ in height (numbers 19-23 in Fig. 5a); and d) small round-to-elliptical ring-like 230 features, up to c. $600 \mathrm{~m}$ in diameter and $15 \mathrm{~m}$ high, with an internal depressed area covered by sediments (numbers 24 and 25 in Fig. 5a). A large elliptical elevation (Baixa do Ambrósio, 1.3 km in diameter and about $130 \mathrm{~m}$ high) also stands prominently isolated on the NW portion of this shelf sector. This is a popular recreational diving site and submarine photos of this area abound. These show that this morphology is a pillow-lava cone whose flanks are cut by marine terraces located at different depths (Ricchi et al., 2018). In addition to the conical morphologies, a prominent NNWSSE rocky ridge can be seen in the central-eastern part of the shelf, extending from the coastline to the shelf edge, almost exactly in line with the Pico Alto ridge onshore (see arrow in Fig. $5 \mathrm{a}$ and compare it to Fig. 2). Along this submarine ridge, several N-S linear positive reliefs are present also 239 in line with dykes exposed at the coast (see Fig. 4 and 1ESM), in between Lagoínhas and Ponta do 
In terms of surface area, the sedimentary cover amounts almost the same as the sediment-free

rocky surfaces, i.e., around $50 \%$ each (see Table 1). A total of $0.515 \mathrm{~km}^{3}$ of sediments are deposited on this sector and the ratio volume of sediments/shelf surface area is 0.007 . Sediments are mostly restricted to the outer part of shelf in the NW and in-between the rocky outcrops in the NE (Fig. 9). Deposits are normally very thin (mostly between 0 and $2 \mathrm{~m}$ ), being locally thicker (up to $14 \mathrm{~m}$ ) on local depocenters bordered by sub-vertical escarpments (e.g., the NW-SE oriented small basin located offshore Baia da Cré, and the ENE-WSW oriented basin offshore Ponta do Norte see Fig. 9 and seismic profiles bb' and $\mathrm{cc}^{\prime}$ in Fig. 3ESM).

\subsubsection{Western shelf sector}

This sector is located offshore the western coast of the island from Baía do Mar da Barca to Ilhéu da Vila (Fig. 6a). The coastline is NNW-SSE oriented with sub-vertical sea cliffs up to $75 \mathrm{~m}$ high, entirely carved in the subaerial westward-dipping lava flows and pyroclastic succession of the Anjos Volcanic Complex (Fig. 2). The shelf runs parallel to the coastline and is generally rocky down to c. $-50 /-70$ m. Offshore Campo Grande a NW-SE strip of sedimentary seafloor (Fig. 6a and 9) around $1.7 \mathrm{~km}$ long and c. $150 \mathrm{~m}$ wide separates the shelf in two parts characterized by different widths (c.1.2-1.6 km to the north, c.2 km to the south). In this sector the erosive shelf edge is generally at $-100 /-110 \mathrm{~m}$ along the northern portion, whilst in the southernmost part its depth increases to $-135 /-147$ m (Figs. 6a, 6b and profile dd' in Fig. 4ESM). However, between offshore Campo Grande and Ponta do Poção, the shelf edge has been indented, shallowing its depth up to $50 \mathrm{~m}$.

The lineament located offshore Campo Grande exhibits onshore an arc-shaped escarpment dissected by a set of WNW-ESE and WSW-ENE structures and the Campo Grande fault (CgF in Fig. 6a, Madeira et al., 2015). In this whole area, the rocky outcrops seen in the high-resolution 
bathymetry are frequently cut by these WNW-ESE and WSW-ENE lineaments (see figure ESM1), which are parallel to the dike network seen on the adjacent coast (Zbyszewsky and Ferreira, 1960; Madeira, 1986; Madeira et al. 2015). In a similar fashion, a few well-pronounced NNW-SSE to NNESSW lineaments can be seen cutting the rocky shelf in this area, running approximately parallel to shore and to the Aeroporto Fault further inland (Fig. 4, AF in Fig. 6a and Fig. 1ESM).

The surface of the seafloor in this sector corresponds to $~ 75 \%$ of rocky surfaces and $25 \%$ of sedimentary cover (Table 1). It has total of $0.037 \mathrm{~km}^{3}$ of sediments and the ratio volume of sediments/shelf surface area is 0.003 . Sediments are therefore restricted to a few scattered patches at -100/-120 $\mathrm{m}$. These are also present inside the WNW-ESE oriented lineament offshore Campo Grande, with thicknesses less than $5 \mathrm{~m}$, which increase up to c. $10 \mathrm{~m}$ at the shelf edge (Fig. 9).

\subsubsection{Southern shelf sector}

This sector is located offshore the southern coast of the island from Ilhéu da Vila to Ponta do Castelo (Fig. 7a). In the western-most portion to Ponta da Marvão, the coastline is very irregular in plan-view, with cliffs mostly formed by SW-dipping lava flows and pyroclastic products of the Anjos Volcanic complex (Fig. 2). From Ponta da Marvão to Ponta do Malbusca, the coastline exhibits an arcuate shape due to the occurrence of a $6 \mathrm{~km}$-wide bay (Praia Formosa Bay, Fig. 7a), bounded by up to $200 \mathrm{~m}$-high, sub-vertical sea cliffs. These are cut in a sequence comprising the Anjos Volcanic Complex lava flows at the base, overlapped by marine sediments and submarine/subaerial volcanic products of both the Touril and the Pico Alto Volcanic Complexes

(Fig. 2). From Ponta da Malbusca to Ponta do Castelo the coastline is made of steep cliffs, carved on the Touril and Pico Alto sequences (Fig. 2). 
The southern shelf has an irregular morphology, with its edge showing a configuration that roughly mimics the coastline west of Ponta da Malbusca. The westernmost portion of the shelf is around $2 \mathrm{~km}$ wide, up to the eastern end of Praia Formosa Bay, after which it is reduced to c. $1 \mathrm{~km}$ offshore Ponta da Malbusca. Eastwards it enlarges again, increasing to up to $2.6 \mathrm{~km}$ in width offshore Ponta do Castelo, at the SE edge of the sector (Figs. 7a and 7b). The depth of the erosive shelf edge follows a similar trend, i.e., deeper where the shelf is wider and shallower when it is narrower. Between south of Ilhéu da Vila to Praia Formosa Bay it is $80 / 90 \mathrm{~m}$ (although can reach $120 \mathrm{~m}$ in places), while it is in the range of 50/90 $\mathrm{m}$ at Ponta da Malbusca. Then, the shelf edge depth progressively increases to a maximum value of $142 \mathrm{~m}$ offshore Ponta do Castelo (Figs. 7a, 7b and profile ee' in Fig. 5ESM).

A dense network of NNW-SSE and NNE-SSW trending lineaments, $0.5 \mathrm{~km}$ to $2 \mathrm{~km}$ long and with escarpments up to $15 \mathrm{~m}$ high, dissects the shelf from the coastline down to its edge, creating a succession of rocky structural high interspersed by sediment-covered depressed areas (Figs. 7a, 9 and seismic profile ff' in Fig. 6ESM). The most evident features are located offshore Vila do Porto, Praia Formosa Bay and Ponta da Malbusca, also having a clear morphological expression onshore (Fig. 7a). The lineaments that compartmentalize the shelf show an orientation similar to the dike network exposed all along this stretch of coastline (see Zbyszewsky and Ferreira, 1960 and Madeira, 1986), (Fig. 7a) and, in some cases, can be followed to the outer shelf. The western Fault of Malbusca (FM in Fig. 7a) also continues offshore, as expressed by a small NNE-SSW linear escarpment.

The distribution of sedimentary cover and rocky surfaces is very similar to the northern sector, around $50 \%$ each (Table 1). This shelf sector has a total of $0.221 \mathrm{~km}^{3}$ of sediments and a ratio volume of sediments/shelf surface area of 0.012 . The distribution of the sediments and their thickness is highly variable being from $<6 \mathrm{~m}$ (offshore Ilhéu da Vila) up to 15-20 m (offshore Praia 
Formosa Bay, Fig. 9, seismic profile ff' in Fig. 6ESM and seismic profile gg' in Fig. 7ESM). Offshore

Praia Formosa and west of Ponta da Malbusca the sediments cover most of the shelf, whilst offshore Ilhéu da Vila and from Ponta do Malbusca to Ponta do Castelo the sediments cover only the outer shelf with a gradually decreasing thickness towards the shelf edge (Fig. 9).

\subsubsection{Eastern shelf sector}

This sector is located offshore the eastern coast of the island from Ponta do Castelo to Ponta do Norte. The coast is very irregular in plan-view, being characterized by several embayments and promontories, with steep cliffs carved in the eastward-prograding lava-delta sequences of the Pico Alto Volcanic Complex (Fig. 2). The NNW-SSE oriented shelf runs parallel to the coastline and is c. 0.6-2.4 km wide, being wider offshore Ponta do Castelete and São Lourenço bay (Figs 8a and 8b). The erosive shelf edge depth varies mostly between $80 \mathrm{~m}$ and $100 \mathrm{~m}$ between Ponta do Norte and the shelf edge embayment offshore Pontinha, whilst south of Potinha it is much shallower, being between $50 \mathrm{~m}$ and $100 \mathrm{~m}$ (Figs. $8 \mathrm{a}$ and $8 \mathrm{~b}$ ). Rocky outcrops are frequently extended down to the shelf edge, where in places they form eastward-dipping ramps, with landward lips up to few meters high (Fig. 8a and seismic profile hh' in Fig. 8ESM). Apart from some small-scale indentations affecting the shelf edge, the eastern sector exhibits only an evident embayment that dissects the shelf at c. $-60--80$ m offshore Pontinha, in front of a concave cliff on the coast (Fig. 8a).

The distribution between the sedimentary cover and rocky surfaces is very similar to the northern and southern sectors, with $54 \%$ corresponding to sediments and $46 \%$ corresponding to rocky surfaces. This sector has a total of $0.187 \mathrm{~km}^{3}$ of sediments and a ratio volume of sediments/shelf surface area of 0.015 . Along the eastern shelf sector the sediments fill some depressions bordered by rocky outcrops and cover the shelf down to c. $-70 \mathrm{~m}$, showing a thickness 
variable from 2 to $15 \mathrm{~m}$ (Fig. 9). The most extensive sediment accumulation, lying offshore Pontinha is a depression between rocky outcrops (Figs. 9 and 9ESM).

\subsection{Wave regime around Santa Maria Island}

The ERA outputs of Santa Maria wave properties suggest that the prevailing swells approach Santa Maria Island from the northwest (35\%) and west (22\%), with average significant wave heights $\left(H_{s}\right)$ of $2.14 \mathrm{~m}$ and $2.44 \mathrm{~m}$ respectively (Fig. 10 and Table 1). Waves from north and northeast are also frequent (respectively $19 \%$ and 12\%) but lower (respectively $\mathrm{H}_{\mathrm{s}}$ of $1.92 \mathrm{~m}$ and $1.83 \mathrm{~m}$ ). The remaining directions are insignificant $(<5 \%$ each), however waves from the southwest can still reach $2.45 \mathrm{~m}$, but only during $5 \%$ of the year.

\section{Discussion}

\subsection{Sediment distribution on the shelf}

In principle the shelf sectors surrounding the eastern part of Santa Maria should be filled with more sediment because cliffs are higher and streams are more abundant. In what concerns accommodation space the western, southern and eastern shelf sectors have similar areas, hence similar space to accommodate deposits (see Table 1). However, the western shelf is mostly sediment-free, with deposits only on the outer shelf and very thin (c. $2 \mathrm{~m}$ thick, Fig. 9). The ratio volume of sediments to area of the shelf in this sector is the lowest $(0.003)$ and around one quart to one fifth of the southern and eastern sectors (respectively 0.012 and 0.015 ) The southern and eastern shelf sectors exhibit then a wider sedimentary cover (around $50 \%$ of the seafloor), but mostly located in the middle to outer shelf. The northern sector shows a similar sediment distribution pattern to the southern and eastern sectors, although being much wider. The deposits 
are very thin (c. $2 \mathrm{~m}$ ) and are mostly on the middle to outer shelf. The fact that nearshore areas of the four sectors are mostly sediment-stripped, despite that most sediments should be produced from cliff erosion is somehow puzzling. This sediment distribution pattern is also seen in other islands of the Azores archipelago such as Faial and Pico and related with high wave energy of this archipelago (Quartau et al., 2012; Quartau et al., 2015b). At Santa Maria this pattern is exacerbated on the western sector relatively to the southern and eastern sectors because this sector is more exposed to the dominant waves, hence transport of sandy sediments to deeper areas is higher and these are probably lost to the slope. In addition, this sector has a poorly developed subaerial drainage and the cliffs are smaller, so fewer sediments accumulate nearshore. Sediments of the southern and eastern shelf sectors, being on the leeward side of the island are less easily transported offshore and consequently may rest at shallower depths (from 35/40 m downwards). The presence of preserved small terraces and wave-cut notches attributed to the last interglacial (and older interglacials) along the SE, E and NE shores (Ramalho et al., 2017) also suggests that wave influence is also lower in these sectors, otherwise these morphologies would have been obliterated receding cliff erosion. In addition, these sectors are partially or entirely adjacent to the higher and rainier side of the island, with a more evolved subaerial drainage, which presumably delivers higher quantities of sediments that then accumulate nearshore. The northern sector is also exposed to the dominant waves as the western sector. However, given that this sector is much wider, sediments are probably not transported much further than the middle to outer shelf and thus are not entirely lost to the slope, leading to a higher sediment accumulation when compared with the western sector. Nevertheless, due to such a large accommodation space, the ratio volume of sediments to area of the shelf in this sector is still the second lowest $(0.014)$ after the western sector. 
The shelf around Santa Maria lacks well-developed sedimentary bodies as those recognized on

other islands of the Azores and the Mediterranean Sea where some portions of the shelf are covered by up to 30-40 m thick volcaniclastic sequences (Chiocci and Romagnoli, 2004; Quartau et al., 2012; Casalbore et al., 2017; Romagnoli et al., 2020). Given that Santa Maria is much older and eroded for a longer period of time should not the shelf have thicker deposits? We believe that the thin sediment cover offshore Santa Maria can be explained by three main reasons:

1. Increasing wave attenuation with shelf width. As shelves became wider, not only the space for sediment accommodation increases, but the energy reaching the coastline decreases due to wave attenuation over wider and shallower shelves (Quartau et al., 2010). Consequently, the lower sediment production by cliff retreat and the higher accommodation space explains the thin cover around Santa Maria shelf.

2. Santa Maria Island is a low and small island, with less precipitation and lower rates of stream erosion when compared with other Azorean Islands (which exhibit rainfall regimes frequently above $2000 \mathrm{~mm} /$ year, AEM \& IMP, 2012). Thus, sediment production is likely dominated by cliff erosion. On the other hand given that island is mostly bound by low cliffs, their erosion produces less sediments than in taller islands.

3. Preservation issues, i.e., the weaker potential for preservation of depositional sequences on the shelves of reefless volcanic islands that are subjected to highly-energetic wave regimes. The Azores archipelago is considered an energetic environment in terms of winds and wave action (Andrade et al., 2008; Quartau et al., 2012; Rusu and Guedes Soares, 2012). In these settings, sediments tend to be transported offshore. Furthermore, as sea level falls, most of the sediments are transported below the shelf edge, leaving the shelves completely stripped of sediments. This cycle is repeated every glacio-eustatic oscillation, preventing the 

accumulation of several depositional sequences, as seen on continental shelves (Ávila et al, 2008; Quartau et al., 2012).

The preservation issues also apply to other volcanic ocean islands subjected to high wave energy regimes. However, on the case of Santa Maria, the two previous reasons are more relevant and probably are enough to explain why Santa Maria lacks thicker sedimentary deposits in its shelf.

\subsection{Mass wasting processes}

Hampton et al. (1996) and Locat and Lee (2002) suggested several mechanisms for submarine landslide triggering. These may include oversteepening, seismic and storm-wave loading and the incohesive nature of the sediments. The subaerial and submarine flanks of volcanic islands are prone to be affected by large-scale sector collapses, as attested by both collapse scars and submarine deposits seen in archipelagos such as the Hawaii (Moore et al., 1994), Canaries (Masson et al., 2002), Cape Verde (Masson et al., 2008), Aeolian (Romagnoli et al., 2009a; Romagnoli et al., 2009b), Aleutians (Montanaro and Beget, 2011), Azores (Costa et al., 2015; Quartau et al., 2015b) and Madeira (Quartau et al., 2018a). Large-scale flank collapses have been proposed for Santa Maria by Sibrant et al. (2015) but at least the younger collapse proposed by these authors is at odds with onshore field studies documented by Ramalho et al. (2017), and submarine evidence for these collapses is absent. However, small scale mass wasting features were identified at the edge of the insular shelf surrounding Santa Maria Island, and these are mostly concentrated on the northern and southern sectors. The largest scars are located along the NE shelf edge, between the areas offshore Ponta do Norte and Baía da Cré, and exhibit a wide 
semicircular shape (Fig. 5a). Several gully heads, with an elongated shape, are also found at the southern shelf edge, between the areas offshore Vila do Porto and Praia Formosa (Fig. 7a). These morphological differences might be related to the processes responsible for the formations of the scars. Along the edge of the NE shelf sector, the scars are apparently controlled by the distribution of the eroded cones and the rocky outcrops on the shelf (Fig. 5a). The areas between the cones/outcrops are probably composed of more friable materials, thus representing a possible lithological weakness, and a preferential pathway for sediment reworking. Despite the fact that nowadays the wide northern shelf prevents any direct stream discharge onto the outer shelf and the upper submarine slope beyond the shelf break, during lowstands sedimentary flows probably were able to reach these areas, carving the head of those "proto-gullies".

Cones are absent along the southern shelf sector, where the elongated morphology of the scars seem to reflect instead NE-SW striking structural weakness corridors, related to the faults that extend to the south of the island and affect the shelf inducing localized erosion (Fig. 7a). The same structural control might be inferred for the formation of the narrow scar located at the shelf edge offshore Ponta dos Frades, in the northern shelf sector (Fig. 5a), being probably the continuation of the faults recognized onshore (Madeira et al., 2015) and on the inner part of the shelf (Ricchi et al., 2018). Similar features can be found on the NE, southern and eastern shelf sectors where likely fault-controlled basins coincide with the scars of shelf-edge landslide (Fig. 9 and profile b-b' in Fig. 3ESM, profile f-f' in Fig. 6ESM and profile i-i' in Fig. 9ESM).

In the case of Santa Maria, it appears that on the southern and in some places on the eastern shelves and northern shelf these mass-wasting processes are mostly controlled by tectonics, because scars appear to be the extension of onshore tectonic features. However, on the northern shelf sector, tectonics appears to play a smaller role. On these sites it is more likely that the accumulation of incohesive sediments near the shelf edge (with high gradients) might trigger 
455

456

457

458

459

460

those landslides as suggested by Casalbore et al. (2015) in Terceira Island, Quartau et al. (2012) in Faial Island, Quartau et al. (2018a) and Santos et al. (2019) in Madeira archipelago, promoting shelf edge retreat. A quite similar setting is found in other shelves around Italian islands, such as Vulcano (Romagnoli et al., 2013), Lipari (Casalbore et al., 2016a), and Ventotene islands (Casalbore et al., 2016b), evidencing how the shelf edge is susceptible to landsliding processes. Most of these islands are volcanic active, thus the production of volcanogenic sediment is higher favoring the widespread occurrence of small-scale mass wasting, especially where thick volcanogenic aprons are present. On the western side of Santa Maria, probably due to the scarcity of sediments and faults there are no significant scars at the shelf edge.

\subsection{New insights on the evolution of Santa Maria Island from submarine morphologies}

Here we discuss the evolution of Santa Maria Island, based on the analysis of the morphologic parameters of the shelf (erosive shelf edge depth, shelf width, and type of submarine morphologies, Figures 5-8 and Table 1).

\subsubsection{Insights from the shelf width}

Generally, on volcanic islands a correspondence between shelf width and age of volcanic products outcropping onland is found (Menard, 1983). The width/age relationship is associated to the fact that the shelf width increases with increasing time as shorelines retreat with prolonged exposure to marine erosion (Quartau et al., 2010, 2012, 2014; Romagnoli, 2013; Romagnoli et al., 2018).

At Santa Maria this relationship can be better observed between the two width/age extremes, the northern shelf (up to c. $8.7 \mathrm{~km}$ ), likely carved in the c. $5.8 \mathrm{Ma}$-old Anjos volcanic products, and 
the eastern shelf $(2.4 \mathrm{~km})$, carved in the c. 4.1-3.5 Ma old products of the Pico Alto volcanic Complex (Figs. 2 and 4). However, the western shelf shows a dramatically lower width (up to c. 2.3 $\mathrm{km}$ ) with respect the northern one (up to c. $8.7 \mathrm{~km}$ ), despite both sectors are carved in the Anjos volcanic products and are similarly exposed to the same dominant waves. Remarkably, the western sector shelf is generally narrower than the southern one $(2.6 \mathrm{~km}$, also carved in the Anjos volcanic units) and with similar width to the eastern sector $(2.4 \mathrm{~km})$. This apparent incongruence can be explained by the paleogeography of the island in its earlier stages of growth. The western subaerial side of the island is interpreted as an uplifted shelf that, at the onset of the uplift (3.5 Ma), was entirely submerged (Fig. 11) as suggested by presently exposed subaerial marine terraces (Ramalho et al., 2017; Ricchi et al., 2018). The width of the western shelf, if measured from the paleo-coastline attributed to $3.5 \mathrm{Ma} \mathrm{BP}$ is between $5.3 \mathrm{~km}$ and $8.5 \mathrm{~km}$ (Fig. 11). This explains why the western shelf, today is not wider than the leeward and younger southeastern and eastern shelves. However, it does not explain why the northern is presently much wider than the western shelf. Given that both northern and western shelves are exposed to similar wave energy they should have similar widths (Figs. 5 and 6 and Table 1ESM).

\subsubsection{Insights from the shelf edge depth}

The analysis of the shelf edge depth might also help us in our understanding (Figs. 5-8). The erosive shelf edge depth is related to sea level coeval to the shelf formation; therefore this morphological feature can be used as a marker of palaeo sea levels, and thus be used to assess subsequent vertical movements affecting the volcanic edifices (Quartau et al. 2014; 2016, Romagnoli et al., 2018, Lucchi et al., 2019). Since glacial eustatic sea level never reached depths below $125 \mathrm{~m}$ in the last 3.5 Ma (Bintanja and van de Wal, 2008; de Boer et al., 2010), so any part of the shelf that is presently located below this depth should have experienced net subsidence 
504

Given that Santa Maria was affected by early subsidence prior to a reversal into an uplift trend at 3.5 Ma (Ramalho et al., 2017), the portions of the shelf exhibiting the deepest erosive edges can be considered the oldest since they underwent the largest submergence after formation. According to the history of vertical movements reconstructed for Santa Maria (Ramalho et al., 2017; Ricchi et al., 2018), the northern shelf sector, being the deepest of all (erosive shelf edge depth down to $-170 \mathrm{~m}$, Figs. 5a and 5b), can be thus considered the oldest in formation. Deep (>$125 \mathrm{~m}$ ) shelf edges have been also identified offshore the western sector of the island. However, in this shelf sector the maximum edge depth is $154 \mathrm{~m}$ (Figs. 5 and 6), indicating that it has suffered less subsidence than the northern shelf. Being likely carved in the products of the Anjos Volcanic Complex (Fig. 2) this shelf sector might be younger than the northern portion of the shelf.

Along the southern shelf sector, the shelf exhibits a more complex morphology and the shelf edge depth has a strongly irregular trend mostly around $80 / 100 \mathrm{~m}$ and being locally at $50 / 60 \mathrm{~m}$ (Fig. 7). The deeper shelf edge offshore Ponta do Castelo (147 m) is in agreement with the inferred subsidence processes experienced by the island and the relatively old age of this shelf sector. It is comparable to the maximum depth along the western sector (154 m, Fig. 6), suggesting that the southeastern portion of Santa Maria could be as old as the western portion of the island if they had been exposed to the same vertical movements.

The eastern shelf shows shelf edge depths not deeper than $100 \mathrm{~m}$, contrary to the remaining sectors that show depths below $125 \mathrm{~m}$. This is because when Pico Alto volcanism ended, the island was on a turning point in terms of vertical movements (see Fig. 6 of Ramalho et al., 2017). It was the beginning of the uplift trend, so the erosional shelf edge of this sector never experienced subsidence and is now always well above $125 \mathrm{~m}$. 


\subsubsection{Insights from submarine morphologies}

\subsubsection{Northern shelf sector}

The morphology of the NW inner shelf shows, from Baía do Mar da Barca to Baía da Cré, a 3 $\mathrm{km}$ wide belt of flat rocky outcrops that is very similar to those that can be seen on the western shelf (Figs. 5a and 6a). This suggests that, most likely, this area was carved on the Anjos Volcanic Complex. We believe that an earlier part of the island, probably older than the products of the Anjos Volcanic Complex, lies offshore those rocky outcrops on the northern shelf. This limit cannot be followed eastwards due to the profusion of eroded prominent reliefs existing in this portion of the shelf.

From Baía da Cré to the east, all rocky features are interpreted as volcanic cones or other type of eruptive centers, albeit being of different age and having experienced different degrees and styles of differential erosion. Type (a) described in section 4.1.1 are interpreted either as volcanic necks exposed by differential erosion, or also as pillow mounds. Type (b), with their concentric nature, are interpreted as old, well-consolidated strombolian cinder-and-scoria cones exposed and truncated by marine erosion. It is unlikely these are recent surtseyan cones, given that surtseyan cones are more friable and typically erode to a flat platform (notwithstanding some concentric features), as the recent surveys of Surtla, Jólnir and Syrtlingur (Surtsey, Iceland; see Romagnoli \& Jacobson, 2015) suggest. These cones are probably contemporary of either the Porto Formation or the Anjos Volcanic Sequence, given their inferred subaerial nature and the fact that the only time relative sea level was low enough to allow their formation was during the period between 5.8 and 5.3 Ma (see Figs. 6 and 7 of Ramalho et al. 2017). In a similar fashion, type (c) cones are interpreted as subaerial cones buried by effusive sequences, which are more erosion-resistant than the softer inner core of the cinder cones. Given this, and the fact that these cones were buried by effusive sequences that are in continuity with the Anjos Volcanic sequence onshore, and 
551 given that they do not exhibit any of the prominent concentric morphologies typical of type (b) 552 cones, these morphologies are interpreted to correspond to eroded surtseyan cones of the 553 Cabrestantes Formation. Finally, type (d) cones, given their very pristine ring-like morphologies, 554 with very low degrees of erosion, are interpreted as very young volcanic cones, perhaps younger 555 than any structure found onshore.

556 The NNW-SSE submarine rocky ridge (Fig. 5a) that extends offshore Ilhéu das Lagoínhas is in 557 clear alignment with both the dykes that cross-cut the Anjos Volcanic Complex along the adjacent 558 coastline and the Pico Alto's ridge. This suggests long-lived fissural volcanism roughly oriented N-S 559 in this part of the island, both during the Anjos and Pico Alto's volcanic phases. This inference is 560 also supported by the presence of elongated morphologies interpreted as dykes exposed by 561 differential erosion (Figs. 4 and 1ESM).

562 The pillow-lava cone of Baixa do Ambrósio at the NW edge of the northern shelf (Fig. 5a) is not 563 directly associated to any of the volcanic complexes making up Santa Maria Island. The lack of 564 dated samples prevented us to make any inference regarding its earlier growth. The depth of its 565 top $($ c. $50 \mathrm{~m}$ ) suggests that probably it is younger with respect the rest of the northern shelf 566 sector; otherwise it would be a more flat-topped cone. On its flanks, Ricchi et al. (2018) recognized 567 a set of submerged marine terraces from $70 / 80 \mathrm{~m}$ to $120 / 140 \mathrm{~m}$. The shallowest terraces are 568 considered to be the oldest and were likely carved at least since 866 ka (Ricchi et al., 2018), 569 suggesting that the cone is older than this age.

We therefore infer that all these eroded cones are covering a "proto-Santa Maria Island" on 571 which the outer northern shelf was carved. This shelf is much wider than the western shelf and the 572 shelf edge deeper. The occurrence of an older volcanic edifice offshore the northern portion of the 573 island had already been proposed by Ramalho et al. (2017), based on the wide northern shelf. But 
now, an improved insight can be taken from the interpretation of the deeper shelf edge and highresolution images of the submarine morphologies.

\subsubsection{Western shelf sector}

The morphology of this sector shows a $\sim 1-2 \mathrm{~km}$ wide belt of flat rocky outcrops that is very similar to those that can be seen on the NW inner shelf (Figs. 5a and 6a). This suggests that, most likely, this area was carved on Anjos Volcanic Complex.

\subsubsection{Southern shelf sector}

This shelf sector shows a $\sim 0.7-2.3 \mathrm{~km}$ wide belt of flat rocky outcrops (Fig. 7a) that are very similar to those on the NW inner shelf and western shelf (Figs. 5a and 6a). These rocky outcrops are separated by sedimentary bottoms that correspond to fault controlled basins. The similarity with the NW inner shelf and western shelf suggests that, most likely, this area was also carved on Anjos Volcanic Complex.

\subsubsection{Eastern shelf sector}

The association of the eastern shelf sector to the Pico Alto products is supported by the outer shelf morphology, which fin-like outward dipping rocky surfaces (Fig. 8 and seismic profile hh' in Fig. 8ESM), interpreted as preserved substructural surfaces of the foreset units of Gilbert-type lava-fed deltas. Effectively, these morphologies are in structural continuity with the eastwarddipping foreset units of the lava-fed delta sequences that crop out all along the eastern coast of the island (e.g. see Figs. 3G and 3H of Ramalho et al. 2017), which extend from the passage zone (between subaerial topset and submarine foreset units) currently located up to c. $130 \mathrm{~m}$ in elevation to present-day sea level (Ramalho et al., 2017). These observations therefore suggest 
that the eastern submarine upper slope of Santa Maria corresponds to the outer submarine slopes of former Gilbert-type lava-fed deltas, i.e. are constructional morphologies contemporaneous of the eastward expansion of the Pico Alto volcanic edifice, prior to uplift and erosion of the shelf.

\section{Conclusions}

The morphologic analysis of the shelf surrounding Santa Maria Island complemented with the known geological history of the subaerial island allowed us to improve our understanding of the island's evolution and the processes which have shaped its shallow submerged portions.

The shelves surrounding Santa Maria are mostly sediment-starved. Around $50 \%$ of the shelf is rocky and sediment thickness is on average less than $2 \mathrm{~m}$. A few depocenters exist, however, with thicknesses up to $14 \mathrm{~m}$, but these are clearly fault-controlled basins. The lack of thicker and older submarine deposits that should have accumulated by erosion of the subaerial flanks of the island are related with the high wave energy in the Azores and the cyclicity of sea-level changes. High wave energy tends to transport sediments offshore and during sea level falls, sediments that normally accumulate on the shelf are swept offshore until they are lost to the slopes as they cross the shelf edge. In the present-day, and since shelves are wide, waves tend to attenuate their energy, eroding the cliffs with less efficiency. In addition, it has lower cliffs and rains less, when compared to other studied islands, so fewer sediments are expected to be delivered from the island to the coastline. Thus, not only fewer sediments are produced, but also larger accommodation spaces (wider shelves) preclude the existence of thicker submarine deposits, as found on other studied volcanic islands.

Small mass-wasting features were found on the shelf edge of Santa Maria. These are mostly restricted to the northern and southern shelves, with only one evident scar on the eastern shelf. 
However, different processes appear to be responsible for such features. On the southern and eastern shelf sectors, is mostly tectonics that controls the location of mass-wasting morphologies, with faults extending offshore and reaching the shelf break. On the northern shelf, the predisposing factor is mostly the accumulation of unconsolidated sediments near the edge.

Based on the analysis of the shelf geomorphic features (shelf width, erosive shelf edge depth and morphology) and the correlation with volcanic sequences outcropping on the island, we were able to improve our understanding of Santa Maria geological evolution. We suggest that given the wide extension of the northern shelf, its outer part belongs to an older and undated volcanic sequence of Santa Maria that predated the Cabrestantes and Porto Formations. The mid-to inner northern shelf, as well as the western and southern shelves were probably carved mainly on the products of Anjos Volcanic Complex, whilst the eastern shelf results from erosion of the products of Pico Alto Volcanic Complex. The present-day narrow width of the western shelf, when compared with the southern and eastern shelves, which are more protected to wave erosion, can be explained by the uplift mechanism that raised part of the western shelf, originally $~ 5.3-8.5 \mathrm{~km}$ wide, leaving now a $2 \mathrm{~km}$ wide shelf.

This work shows that, despite the fact that Santa Maria Island is much older than islands addressed in previous shelf studies, the various geological processes acting on the shelf can still leave significant morphological imprints that provide us important knowledge about the evolutionary history of this island.

\section{Acknowledgments}

The acquisition of multibeam bathymetry and seismic reflection profiles were funded by Fundação para a Ciência e a Tecnologia (FCT) through the PLATMAR project (Development of volcanic island shelves: insights from Sta. Maria Island and implications on hazard assessment, habitat mapping 
646

647

648

649

650

651

652

653

654

655

656

657

658

659

660

661

662

663

664

665

and marine aggregates management, PTDC/GEO-GEO/0051/2014). The authors are grateful to the crew of R/V Arquipélago and Pedro Afonso for all their help in the preparation and execution of the geophysical survey. R. Ramalho acknowledges its "Investigador FCT" contract IF/01641/2015 funded by FCT. This study has been developed in the framework of the PhD thesis "Insular shelves as a tool for reconstructing the evolution of volcanic islands" (A. Ricchi, University of Bologna).

\section{References}

Agencia Estatal de Meteorología \& Instituto de Meteorologia de Portugal, 2012. Climate atlas of the archipelagos of the Canary Islands, Madeira and the Azores. p. 78.

Andrade, C., Trigo, R.M., Freitas, M.C., Gallego, M.C., Borges, P., Ramos, A.M., 2008. Comparing historic records of storm frequency and the North Atlantic Oscillation (NAO) chronology for the Azores region. The Holocene 18, 745-754.

Ávila, S.P., Madeira, P., Silva, C.M.d., Cachão, M., Quartau, R., Landau, B., Martins, A.M.d.F., 2008. Local disappearance of bivalves in the Azores during the last glaciation. Journal of Quaternary Science 23, 777-785.

Bintanja, R., van de Wal, R.S.W., 2008. North American ice-sheet dynamics and the onset of 100,000-year glacial cycles. Nature 454, 869-872.

Casalbore, D., Bosman, A., Romagnoli, C., Di Filippo, M., \& Chiocci, F.L., 2016a. Morphology of Lipari offshore (Southern Tyrrhenian Sea). Journal of Maps 12, 77-86.

Casalbore, D., Bosman, A., Martorelli, E., Sposato, A., Chiocci, F.L., 2016b. Mass wasting features on the submarine flanks of Ventotene volcanic edifice (Tyrrhenian Sea, Italy): In Submarine Mass 
668 669 670 671 672 673 674 675 676 677 678 679 680

Movements and Their Consequences, (Eds Krastel et al), Advances in Natural and Technological Hazards Research, 37, 285-293, DOI 101007/978-3-319-00972-8 25

Casalbore, D., Falese, F., Martorelli, E., Romagnoli, C., Chiocci, F.L., 2017. Submarine depositional terraces in the Tyrrhenian Sea as a proxy for paleo-sea level reconstruction: Problems and perspective. Quatern. Int. 439, 169-180.

Casalbore, D., Romagnoli, C., Adami, C., Bosman, A., Falese, F., Ricchi, A., Chiocci, F., 2018. Submarine Depositional Terraces at Salina Island (Southern Tyrrhenian Sea) and Implications on the Late-Quaternary Evolution of the Insular Shelf. Geosciences 8, 20.

Casalbore, D., Romagnoli, C., Bosman, A., Chiocci, F.L., 2011. Potential tsunamigenic landslides at Stromboli Volcano (Italy): Insight from marine DEM analysis. Geomorphology 126, 42-50.

Casalbore, D., Romagnoli, C., Pimentel, A., Quartau, R., Casas, D., Ercilla, G., Hipólito, A., Sposato, A., Chiocci, F.L., 2015. Volcanic, tectonic and mass-wasting processes offshore Terceira Island (Azores) revealed by high-resolution seafloor mapping. Bull. Volc. 77, 1-19.

Chiocci, F.L., Romagnoli, C., 2004. Submerged depositional terraces in the Aeolian Islands (Sicily), in: Chiocci, F.L., D'Angelo, S., Romagnoli, C. (Eds.), Atlas of submerged depositional terraces along the Italian coasts. Memorie Descrittive della Carta Geologica d'Italia. APAT, Roma, pp. 81-114.

Costa, A.C.G., Hildenbrand, A., Marques, F.O., Sibrant, A.L.R., Santos de Campos, A., 2015.

Catastrophic flank collapses and slumping in Pico Island during the last 130 kyr (Pico-Faial ridge, Azores Triple Junction). J. Volcanol. Geotherm. Res. 302, 33-46. 
687 688 689 690 691 692 693 694 695 696 697 698

de Boer, B., Van De Wal, R.S.W., Bintanja, R., Lourens, L.J., Tuenter, E., 2010. Cenozoic global icevolume and temperature simulations with 1-D ice-sheet models forced by benthic 180 records. Ann. Glaciol. 51, 23-33.

Dee, D. P., S. Uppala, A. Simmons, P. Berrisford, P. Poli, S. Kobayashi, U. Andrae, M. Balmaseda, G. Balsamo, and P. Bauer., 2011. The ERA-Interim reanalysis: Configuration and performance of the data assimilation system. Q. J. Roy. Meteor. Soc., 137 (656), 553-597.

Deplus, C., Le Friant, A., Boudon, G., Komorowski, J.-C., Villemant, B., Harford, C.L., Segoufin, J., Cheminée, J.-L., 2001. Submarine evidence for large-scale debris avalanches in the Lesser Antilles Arc. Earth Planet. Sci. Lett. 192, 145-157.

Fernandes, J., 2004. Caracterização Climática das ilhas de S Miguel e Santa Maria com base no modelo CIELO. BSc thesis. Dept. de Ciências Agrárias. Universidade dos Açores, Angra do Heroísmo, p. 210.

Field, M.E., Roy, P.S., 1984. Offshore transport and sand-body formation; evidence from a steep, high energy shoreface, southeastern Australia. J. Sediment. Res. 54, 1292-1302.

Gente, P., Dyment, J., Maia, M., Goslin, J., 2003. Interaction between the Mid-Atlantic Ridge and the Azores hot spot during the last 85 Myr: Emplacement and rifting of the hot spot-derived plateaus. Geochem. Geophys. Geosyst. 4, 8514.

Hampton, M.A., Lee, H.J., Locat, J., 1996. Submarine landslides. Rev. Geophys. 34, 33-59.

Hatton, B. 2019. Hurricane Lorenzo batters mid-Atlantic Azores Islands. ABC News. Associated Press. Retrieved February 9, 2020. 
707

708

709

710

711

712

713

714

715

URL:https://abcnews.go.com/International/wireStory/category-hurricane-batters-mid-atlanticazores-islands-65997843.

Hernández-Molina, F.J., Fernández-Salas, L.M., Lobo, F., Somoza, L., Díaz-del-Río, V., Alveirinho Dias, J.M., 2000. The infralittoral prograding wedge: a new large-scale progradational sedimentary body in shallow marine environments. Geo-Mar. Lett. 20, 109-117.

Hipólito, A., Madeira, J., Carmo, R., Gaspar, J.L., 2013. Neotectonics of Graciosa island (Azores): a contribution to seismic hazard assessment of a volcanic area in a complex geodynamic setting. Ann. Geophys. 56, 1-18.

Krastel, S., Schmincke, H.-U., Jacobs, C.L., 2001. Formation of submarine canyons on the flanks of the Canary Islands. Geo-Mar. Lett. 20, 160-167.

Lebas, E., Friant, A.L., Deplus, C., Voogd, B., 2018. Understanding the Evolution of an Oceanic Intraplate Volcano From Seismic Reflection Data: A New Model for La Réunion, Indian Ocean. J. Geophys. Res. Solid Earth 123, 1035-1059.

Llanes, P., Herrera, R., Gómez, M., Muñoz, A., Acosta, J., Uchupi, E., Smith, D., 2009. Geological evolution of the volcanic island La Gomera, Canary Islands, from analysis of its geomorphology. Mar. Geol. 264, 123-139.

Locat, J., Lee, H.J., 2002. Submarine landslides: advances and challenges. Can. Geotech. J. 39, 193212.

Lourenço, N., Miranda, J.M., Luís, J.F., Ribeiro, A., Mendes Victor, L.A., Madeira, J., Needham, H.D., 1998. Morpho-tectonic analysis of the Azores Volcanic Plateau from a new bathymetric compilation of the area. Mar. Geophys. Res. 20, 141-156. 
Lucchi, F., Ricchi, A., Romagnoli, C., Casalbore, D., Quartau, R., 2019. Late Quaternary paleo sea level geomorphological markers of opposite vertical movements at Salina volcanic island (Aeolian Arc). Earth Surf. Proc. Land., , https://doi.org/10.1002/esp.4651. .

Madeira, J., 1986. Geologia estrutural e enquadramento geotectónico da ilha de Santa Maria, MSc thesis. Dept. de Geologia. Universidade de Lisboa, Lisboa, p. 107.

Madeira, J., Brum da Silveira, A., Hipólito, A., Carmo, R., 2015. Active tectonics in the central and eastern Azores islands along the Eurasia-Nubia boundary: a review, in: Gaspar, J.L., Guest, J.E., Duncan, A.M., Barriga, F.J.A.S., Chester, D.K. (Eds.), Geological Society, London, Memoirs, 44, pp. $15-32$.

Marques, F.O., Catalão, J.C., DeMets, C., Costa, A.C.G., Hildenbrand, A., 2013. GPS and tectonic evidence for a diffuse plate boundary at the Azores Triple Junction. Earth Planet. Sci. Lett. 381, 177-187.

Masson, D.G., Le Bas, T.P., Grevemeyer, I., Weinrebe, W., 2008. Flank collapse and large-scale landsliding in the Cape Verde Islands, off West Africa. Geochem. Geophys. Geosyst. 9, doi:10.1029/2008GC001983.

Masson, D.G., Watts, A.B., Gee, M.J.R., Urgeles, R., Mitchell, N.C., Le Bas, T.P., Canals, M., 2002. Slope failures on the flanks of the western Canary Islands. Earth-Sci. Rev. 57, 1-35.

Mazuel, A., Sisavath, E., Babonneau, N., Jorry, S.J., Bachèlery, P., Delacourt, C., 2016. Turbidity current activity along the flanks of a volcanic edifice: The Mafate volcaniclastic complex, La Réunion Island, Indian Ocean. Sed. Geol. 335, 34-50. 
Meireles, R., Quartau, R., Ramalho, R.S., Rebelo, A.C., Madeira, J., Zanon, V., Ávila, S.P., 2013.

Depositional processes on oceanic island shelves - evidence from storm-generated Neogene deposits from the mid-North Atlantic. Sedimentology 60, 1769-1785.

Menard, H.W., 1983. Insular erosion, isostasy, and subsidence. Science 220, 913-918.

Miranda, J.M., Luís, J., Lourenço, N., 2018. The geophysical architecture of the Azores from magnetic data, in: Kueppers, U., Beier, C. (Eds.), Volcanoes of the Azores. Springer-Verlag Berlin Heidelberg, pp. 89-100.

Mitchell, N.C., Dade, W.B., Masson, D.G., 2003. Erosion of the submarine flanks of the Canary Islands. J. Geophys. Res. 108, 3-1 - 3-11.

Mitchell, N.C., Masson, D.G., Watts, A.B., Gee, M.J.R., Urgeles, R., 2002. The morphology of the flanks of volcanic ocean islands: A comparative study of the Canary and Hawaiian hotspot islands. J. Volcanol. Geotherm. Res. 115, 83-107.

Montanaro, C., Beget, J., 2011. Volcano collapse along the Aleutian Ridge (western Aleutian Arc). Nat. Hazards Earth Syst. Sci. 11, 715-730.

Moore, J.G., Clague, D.A., Holcomb, R.T., Lipman, P.W., Normark, W.R., Torresan, M.E., 1989.

Prodigious submarine landslides on the Hawaiian Ridge. J. Geophys. Res.: Solid Earth 94, 1746517484.

Moore, J.G., Normark, W.R., Holcomb, R.T., 1994. Giant Hawaiian Landslides. Annu. Rev. Earth PI. Sc. $22,119-144$.

Oehler, J.-F., Lénat, J.-F., Labazuy, P., 2008. Growth and collapse of the Reunion Island volcanoes. Bull. Volc. 70, 717-742. 
Quartau, R., Hipólito, A., Mitchell, N.C., Gaspar, J.L., Brandão, F., 2015a. Comment on "Construction and destruction of a volcanic island developed inside an oceanic rift: Graciosa Island, Terceira Rift, Azores" by Sibrant et al. (2014) and proposal of a new model for Graciosa geological evolution [J. Volcanol. Geotherm. Res. 284 (2014) 32-45]. J. Volcanol. Geotherm. Res. $303,146-156$.

Quartau, R., Hipólito, A., Romagnoli, C., Casalbore, D., Madeira, J., Tempera, F., Roque, C., Chiocci, F.L., 2014. The morphology of insular shelves as a key for understanding the geological evolution of volcanic islands: Insights from Terceira Island (Azores). Geochem. Geophys. Geosyst. 15, 18011826.

Quartau, R., Madeira, J., Mitchell, N.C., Tempera, F., Silva, P.F., Brandão, F., 2015b. The insular shelves of the Faial-Pico Ridge: a morphological record of its geologic evolution (Azores archipelago). Geochem. Geophys. Geosyst. 16, 1401-1420.

Quartau, R., Madeira, J., Mitchell, N.C., Tempera, F., Silva, P.F., Brandão, F., 2016. Reply to comment by Marques et al. on "The insular shelves of the Faial-Pico Ridge (Azores archipelago): A morphological record of its evolution". Geochem. Geophys. Geosyst. 17, 633-641.

Quartau, R., Mitchell, N.C., 2013. Comment on "Reconstructing the architectural evolution of volcanic islands from combined $\mathrm{K} / \mathrm{Ar}$, morphologic, tectonic, and magnetic data: The Faial Island example (Azores)" by Hildenbrand et al. (2012) [J. Volcanol. Geotherm. Res. 241-242 (2012) 3948]. J. Volcanol. Geotherm. Res. 255, 124-126.

Quartau, R., Ramalho, R.S., Madeira, J., Santos, R., Rodrigues, A., Roque, C., Carrara, G., Brum da Silveira, A., 2018a. Gravitational, erosional and depositional processes on volcanic ocean islands: 
790

791

792

793

794

795

796

797

798

799

800

801

802

803

804

805

806

807

808

809

Insights from the submarine morphology of Madeira archipelago. Earth Planet. Sci. Lett. 482, 288-

299.

Quartau, R., Tempera, F., Mitchell, N.C., Pinheiro, L.M., Duarte, H., Brito, P.O., Bates, R., Monteiro, J.H., 2012. Morphology of the Faial Island shelf (Azores): The interplay between volcanic, erosional, depositional, tectonic and mass-wasting processes. Geochem. Geophys. Geosyst., 13, Q04012, doi:10.1029/2011GC003987.

Quartau, R., Trenhaile, A.S., Mitchell, N.C., Tempera, F., 2010. Development of volcanic insular shelves: Insights from observations and modelling of Faial Island in the Azores Archipelago. Mar. Geol. 275, 66-83.

Quartau, R., Trenhaile, A.S., Ramalho, R.S., Mitchell, N.C., 2018b. The role of subsidence in shelf widening around ocean island volcanoes: Insights from observed morphology and modeling. Earth Planet. Sci. Lett. 498, 408-417.

Ramalho, R.S., Helffrich, G., Madeira, J., Cosca, M., Thomas, C., Quartau, R., Hipólito, A., Rovere, A., Hearty, P.J., Ávila, S.P., 2017. Emergence and evolution of Santa Maria Island (Azores)-The conundrum of uplifted islands revisited. Geol. Soc. Am. Bull. 129, 372-390.

Ramalho, R.S., Quartau, R., Hóskuldsson, A., Madeira, J., Ventura da Cruz, J., Rodrigues, A., in press. Evidence for late Pleistocene volcanism at Santa Maria Island, Azores? J Volcanol Geoth Res.

Ramalho, R.S., Quartau, R., Trenhaile, A.S., Mitchell, N.C., Woodroffe, C.D., Ávila, S.P., 2013.

Coastal evolution on volcanic oceanic islands: A complex interplay between volcanism, erosion, sedimentation, sea-level change and biogenic production. Earth-Sci. Rev. 127, 140-170. 
Ricchi, A., Quartau, R., Ramalho, R.S., Romagnoli, C., Casalbore, D., Ventura da Cruz, J., Fradique, C., Vinhas, A., 2018. Marine terraces development on reefless volcanic islands: new insights from high-resolution marine geophysical data offshore Santa Maria Island (Azores Archipelago). Mar. Geol. 406, 42-56.

Romagnoli, C., 2013. Characteristics and morphological evolution of the Aeolian volcanoes from the study of submarine portions, in: Lucchi, F., Peccerillo, A., Keller, J., Tranne, C.A., Rossi, P.L. (Eds.), Geological Society, London, Memoirs, 37, pp. 13-26.

Romagnoli, C., Belvisi, V., Innangi, S., Di Martino, G., Tonielli, R., 2020. New insights on the evolution of the Linosa volcano (Sicily Channel) from the study of its submarine portions. Marine Geology 419, 106060.

Romagnoli C., Casalbore D., Bosman A., Braga R., Chiocci F.L. (2013). Submarine structure of Vulcano Volcano (Aeolian Islands) revealed by high-resolution bathymetry and seismo-acoustic data. Marine Geology 338, 30-45.

Romagnoli, C., Casalbore, D., Chiocci, F.L., Bosman, A., 2009a. Offshore evidence of large-scale lateral collapses on the eastern flank of Stromboli, Italy, due to structurally-controlled, bilateral flank instability. Mar. Geol. 262, 1-13.

Romagnoli, C., Casalbore, D., Ricchi, A., Lucchi, F., Quartau, R., Bosman, A., Tranne, C.A., Chiocci, F.L., 2018. Morpho-bathymetric and seismo-stratigraphic analysis of the insular shelf of Salina (Aeolian archipelago) to unveil its Late-Quaternary geological evolution. Mar. Geol. 395, 133-151.

Romagnoli, C., Kokelaar, P., Casalbore, D., Chiocci, F.L., 2009b. Lateral collapses and active sedimentary processes on the northwestern flank of Stromboli volcano, Italy. Mar. Geol. 265, 101119. 
Rusu, L., Guedes Soares, C., 2012. Wave energy assessments in the Azores islands. Renew. Energy 45, 183-196.

Serralheiro, A., Alves, C.A.M., Forjaz, V.H., Rodrigues, B., 1987. Carta Vulcanológica dos Açores. Ilha de Santa Maria na (folhas 1 e 2), scale 1:15,000. Serviço Regional de Protecção Civil dos Açores, Universidade dos Açores and Centro de Vulcanologia, Ponta Delgada.

Serralheiro, A., Madeira, J., 1993. Stratigraphy and geochronology of Santa Maria Island (Azores). Açoreana 7, 575-592.

Sibrant, A.L.R., Hildenbrand, A., Marques, F.O., Costa, A.C.G., 2015. Volcano-tectonic evolution of the Santa Maria Island (Azores): Implications for paleostress evolution at the western EurasiaNubia plate boundary. J. Volcanol. Geotherm. Res. 291, 49-62.

Taylor, B., 2019. Shoreline slope breaks revise understanding of Hawaiian shield volcanoes evolution. Geochem. Geophys. Geosyst. 20, 4025-4045.

Thouret, J.C., 1999. Volcanic geomorphology-an overview. Earth-Sci. Rev. 47, 95-131.

Tsutsui, B., Campbell, J.F., Coulbourn, W.T., 1987. Storm-generated, episodic sediment movements off Kahe Point, Oahu, Hawaii. Mar. Geol. 76, 281-299.

Uppala, S. M., P. Kållberg, A. Simmons, U. Andrae, V. d. Bechtold, M. Fiorino, J. Gibson, J. Haseler, A. Hernandez, and G. Kelly., 2005. The ERA-40 re-analysis. Q. J. Roy. Meteor. Soc. 131 (612):29613012.

Zbyszewski, G., Ferreira, O.V., 1960. Carta Geológica de Portugal-Ilha de Santa Maria (Açores), scale 1:50,000. Serviços Geológicos de Portugal, Lisboa. 
852 Zhao, Z., Mitchell, N.C., Quartau, R., Tempera, F. and Bricheno, L., 2019. Submarine Platform

853 Development by Erosion of a Surtseyan Cone at Capelinhos, Faial Island, Azores. Earth Surf. Proc.

854 Land. 44(15), 2982-3006.

855

856

857 
Fig. 1. Shaded relief map illustrating the geodynamic setting of the islands (western, central and eastern groups) in the Azores Archipelago (islands in white, Santa Maria Island in yellow) and how they straddle the triple junction between the North American (NA), Eurasian (EU) and Nubian (NU) lithospheric plates. MAR: Mid-Atlantic Ridge; PAR: Princess Alice Rift; EAFZ: Eastern Azores Fracture Zone; TR: Terceira Rift; GF: Gloria Fault. Grey shading represents the deformation zone of Terceira rift and dashed lines of the inactive Princess Alice Rift. The upper-right inset shows the geographical setting of the Azores Archipelago within the Northern Atlantic Ocean. The bathymetry is derived from the EMODNET web portal (http://portal.emodnet-bathymetry.eu/) and tectonic structures adapted from Miranda et al. (2018).

Fig. 2. (a) Geological map of Santa Maria Island (modified after Ramalho et al., 2017), and (b) WNW-ESE oriented cross-section. Underlying digital elevation model (DEM) is generated from a 1/5000 scale digital altimetric database from Secretaria Regional do Turismo e Transportes of the Azores Government. Note that the Porto Formation is not visible on the map/section at this scale.

Fig. 3. Dataset used for this study, showing the seismic reflection profiles acquired during the PLATMAR 1/2016 cruise. The multibeam survey covered the area shown by the seismic grid. Blue dots represent location of sound speed profiles collected during the multibeam survey. Bathymetry shown in this figure ( $200 \mathrm{~m}$ resolution) was derived from the EMODNET web portal (http:// portal.emodnet-bathymetry.eu); topography is the same as the one shown in Figure 2.

Fig. 4. Shaded relief map of the multibeam bathymetry. Topography is the same as the one shown in Figure 2. 
Fig. 5. (a) Shaded relief map of the northern shelf sector showing the erosive shelf edge, headwalls scars, extension of tectonic features and volcanic cones. The seismic profile aa' is shown in Fig. 2ESM and seismic profiles bb' $^{\prime}$ and $\mathrm{Cc}^{\prime}$ are shown in Fig. 3ESM. (b) Variation of shelf width and erosive shelf edge depth along the northern sector from west to east (from A to B). Shelf width was only measured on profiles perpendicular to the north coast.

Fig. 6. (a) Shaded relief map of the western shelf sector showing the erosive shelf edge, headwalls scars, and extension of tectonic features. The seismic profile $\mathrm{dd}^{\prime}$ is shown in Fig. 4ESM (b) Variation of shelf width and erosive shelf edge depth along the western sector from north to south (from $C$ to $D)$.

Fig. 7. (a) Shaded relief map of the southern shelf sector showing the erosive shelf edge, headwalls scars, and extension of tectonic features. The seismic profiles ee', $\mathrm{ff}^{\prime}$ and $\mathrm{gg}^{\prime}$ are shown respectively in Figs. 5ESM, 6ESM and 7ESM (b) Variation of shelf width and erosive shelf edge depth along the southern sector from west to east (from $\mathrm{E}$ to $\mathrm{F}$ ).

Fig. 8. (a) Shaded relief map of the eastern shelf sector showing the erosive shelf edge, headwalls scars, and extension of tectonic features. The seismic profiles hh' and ii' are shown in Figs. 8ESM and 9ESM, respectively. (b) Variation of shelf width and erosive shelf edge depth along the eastern sector from north to south (from $\mathrm{G}$ to $\mathrm{H}$ ).

Fig. 9. Thickness map (in metres) of the unconsolidated sediments of the shelf surrounding Santa Maria Island. 
Fig. 10. Offshore significant wave heights in the Santa Maria area derived from ERA 40 and ERA

907 Interim (Uppala et al., 2005; Dee et al., 2011)

908

909 Fig. 11. Reconstruction of the likely extension of the western shelf of Santa Maria Island 3.5 Ma 910 ago, before being partially raised. Color scale of topography is the same as Figure 3. 
1 Table 1 - Extension of the rocky and sedimentary seafloor areas (in $\mathrm{km}^{2}$ and \%) of each shelf sector; measured volume of

2 sediments in each sector; and ratio of volume of sediments of each shelf sector versus its total area.

\begin{tabular}{|c|c|c|c|c|c|c|c|}
\hline \multirow[b]{2}{*}{ Sectors } & \multicolumn{3}{|c|}{ Area $\left(\mathrm{km}^{2}\right)$} & \multicolumn{2}{|c|}{ Area (\%) } & \multirow[t]{2}{*}{ Volume of sediments $\left(\mathrm{km}^{3}\right)$} & \multirow[t]{2}{*}{$\begin{array}{l}\text { Volume sediments/Total shelf } \\
\text { area }\end{array}$} \\
\hline & Sediments & Rocks & Total & Sediments & Rocks & & \\
\hline Northern & 36.820 & 36.240 & 73.060 & 50.397 & 49.603 & 0.515 & 0.007 \\
\hline Western & 3.300 & 9.900 & 13.200 & 25.000 & 75.000 & 0.037 & 0.003 \\
\hline Southern & 9.450 & 9.580 & 19.030 & 49.658 & 50.342 & 0.221 & 0.012 \\
\hline Eastern & 6.530 & 5.670 & 12.200 & 53.525 & 46.475 & 0.187 & 0.015 \\
\hline
\end{tabular}


Fig. 1ESM. High resolution (1200 dpi) shaded relief map of the multibeam bathymetry. Topography is the same as the one shown in Figure 2.

5

Fig. 2ESM. Boomer seismic profile aa' showing the shelf morphology off the NW sector of Santa Maria. Location of the seismic profile in Figs. 5 a and 9.

Fig. 3ESM. Boomer seismic profiles $\mathrm{bb}^{\prime}$ and $\mathrm{cc}^{\prime}$ showing the shelf morphology controlled by faults off the N and NE sector of Santa Maria. Location of the seismic profiles in Fig. 5a and 9. Santa Maria. Location of the seismic profile in Fig. $6 a$. Santa Maria. Location of the seismic profile in Fig. 7a. southern sector of Santa Maria. Location of the seismic profile in Fig. 7a. Santa Maria. Location of the seismic profile in Fig. 7a. 
24 Fig. 8ESM. Boomer seismic profiles hh' showing the shelf morphology off the eastern sector of 25 Santa Maria. Location of the seismic profiles in Fig. 8a.

26

27 Fig. 9ESM. Boomer seismic profiles ii' showing the the shelf morphology controlled by faults off 28 the eastern sector of Santa Maria. Location of the seismic profiles in Fig. 8a. 
Table 1ESM - Six hourly significant wave height $\mathrm{H}_{\mathrm{s}}$ for the quadrant directions and respective frequencies derived from ERA

240 and ERA Interim for the period between 1957 and 2019 (Uppala et al., 2005; Dee et al., 2011).

\begin{tabular}{|c|c|c|c|c|c|c|c|c|c|c|c|}
\hline \multirow{2}{*}{$\begin{array}{c}\text { Wave } \\
\text { originating } \\
\text { direction }\end{array}$} & \multicolumn{9}{|c|}{$\begin{array}{c}\text { Percent frequency }(\%) \\
\text { Significant wave height } H_{s}(\mathrm{~m})\end{array}$} & \multirow{2}{*}{$\begin{array}{l}\text { Sum of percent } \\
\text { frequency }(\%)\end{array}$} & \multirow{2}{*}{$\begin{array}{l}\text { Average } \\
H_{s}(\mathrm{~m})\end{array}$} \\
\hline & $0-1 \mathrm{~m}$ & $1-2 \mathrm{~m}$ & $2-3 m$ & $3-4 m$ & $4-5 m$ & $5-6 m$ & $6-7 \mathrm{~m}$ & $7-8 m$ & $>=8 \mathrm{~m}$ & & \\
\hline $\mathrm{N}$ & 0.99471 & 10.86626 & 5.20769 & 1.40490 & 0.32027 & 0.06699 & 0.02207 & 0.00590 & 0.00020 & 18.88899 & 1.922017 \\
\hline $\mathrm{NE}$ & 0.56254 & 7.96483 & 2.96023 & 0.74180 & 0.15010 & 0.01982 & 0.00332 & 0.00111 & 0.00000 & 12.40375 & 1.830305 \\
\hline $\mathrm{E}$ & 0.15145 & 2.15108 & 0.86000 & 0.29517 & 0.06035 & 0.00528 & 0.00000 & 0.00000 & 0.00000 & 3.52333 & 1.890301 \\
\hline SE & 0.05794 & 0.67366 & 0.40322 & 0.13622 & 0.02203 & 0.00299 & 0.00000 & 0.00000 & 0.00000 & 1.29606 & 2.017559 \\
\hline $\mathrm{S}$ & 0.09557 & 0.72673 & 0.59120 & 0.27056 & 0.05839 & 0.01118 & 0.00000 & 0.00000 & 0.00000 & 1.75363 & 2.204198 \\
\hline SW & 0.19097 & 1.88260 & 1.55349 & 0.89456 & 0.34652 & 0.12226 & 0.02182 & 0.00577 & 0.00098 & 5.01897 & 2.453569 \\
\hline W & 0.77025 & 8.88117 & 6.84695 & 3.62394 & 1.44261 & 0.54584 & 0.18249 & 0.06727 & 0.03071 & 22.39123 & 2.436865 \\
\hline NW & 1.48884 & 17.00499 & 10.67882 & 3.78117 & 1.24923 & 0.35548 & 0.11542 & 0.03660 & 0.01347 & 34.72402 & 2.142374 \\
\hline
\end{tabular}

3 


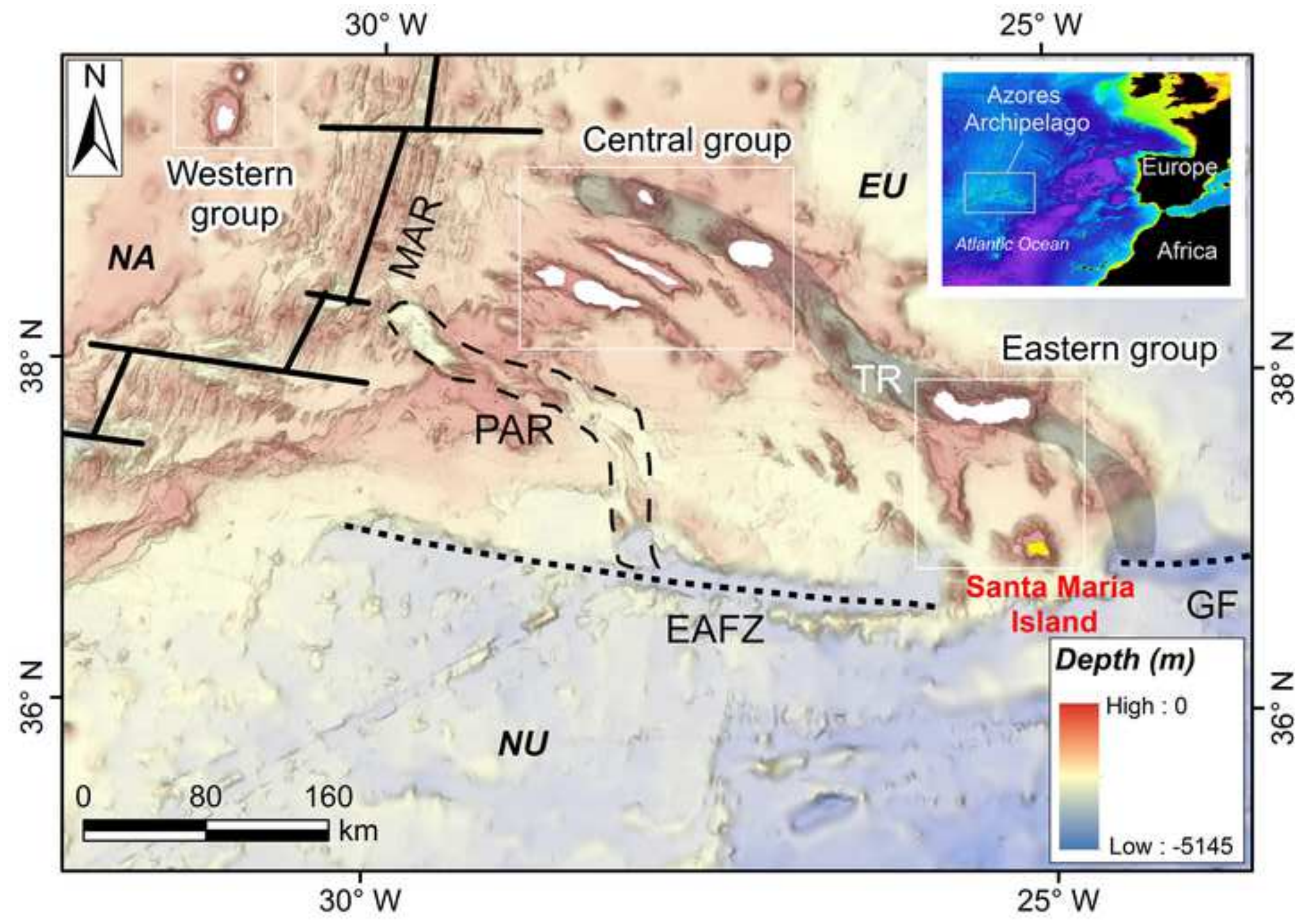




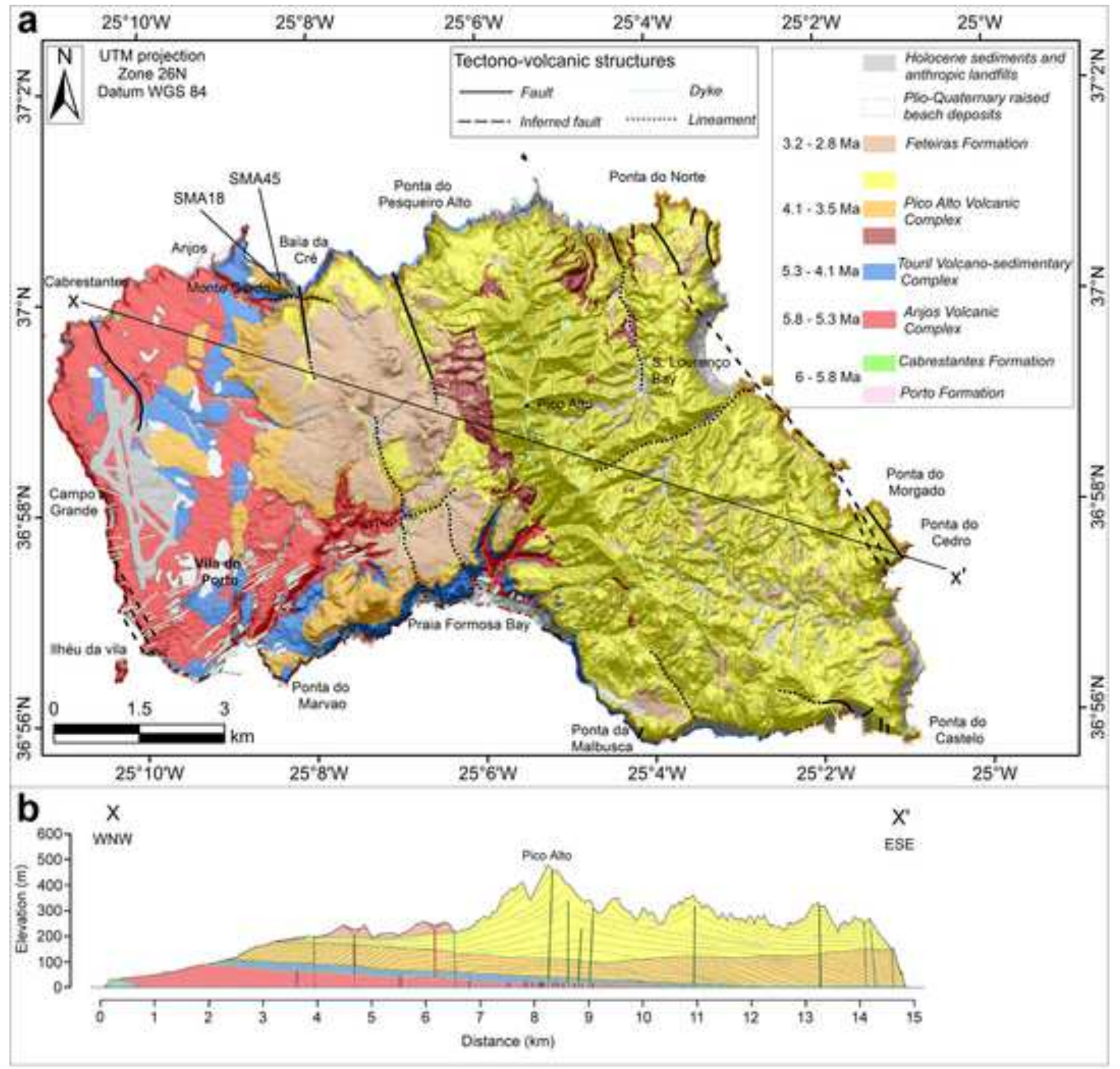




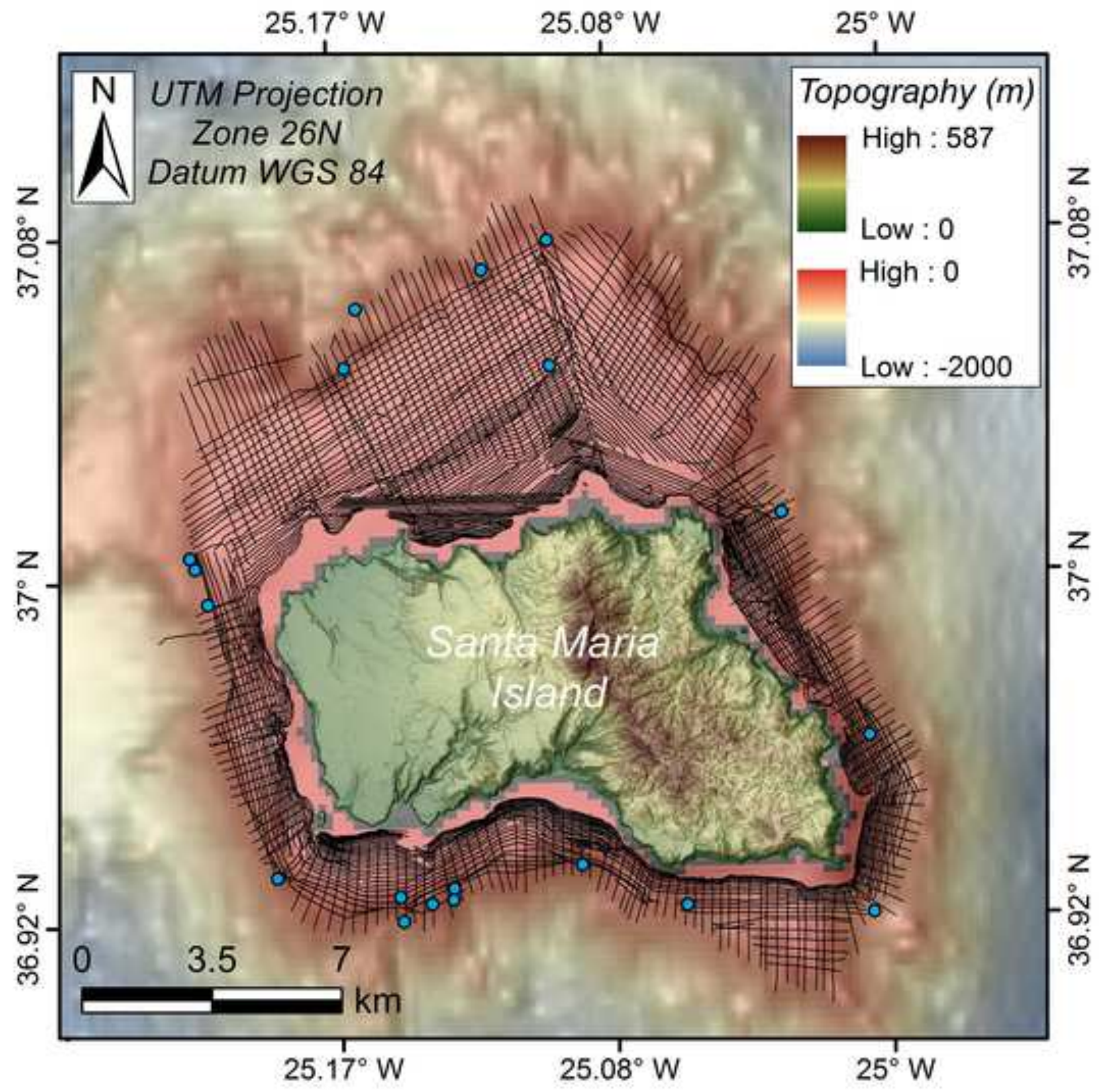




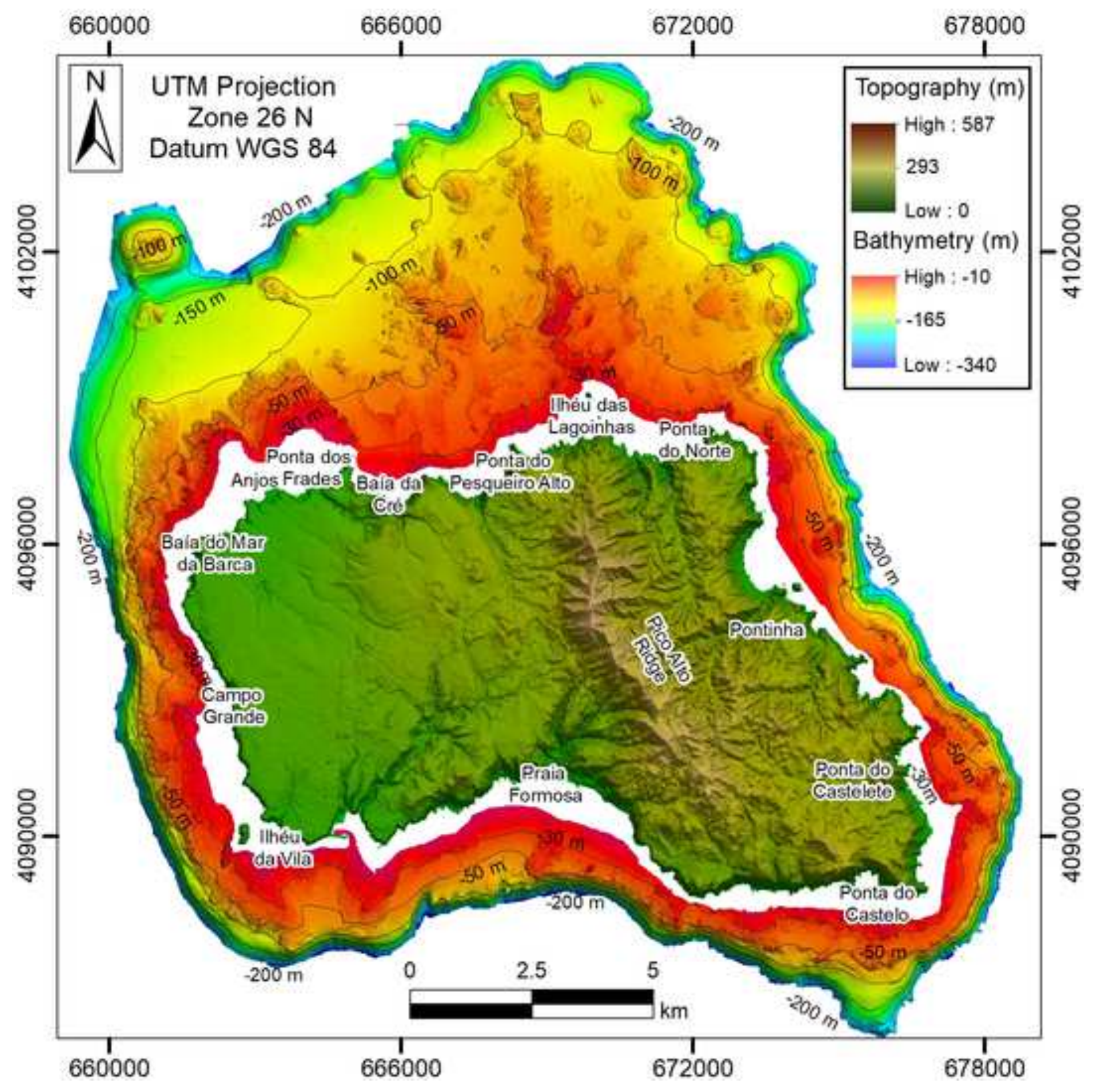




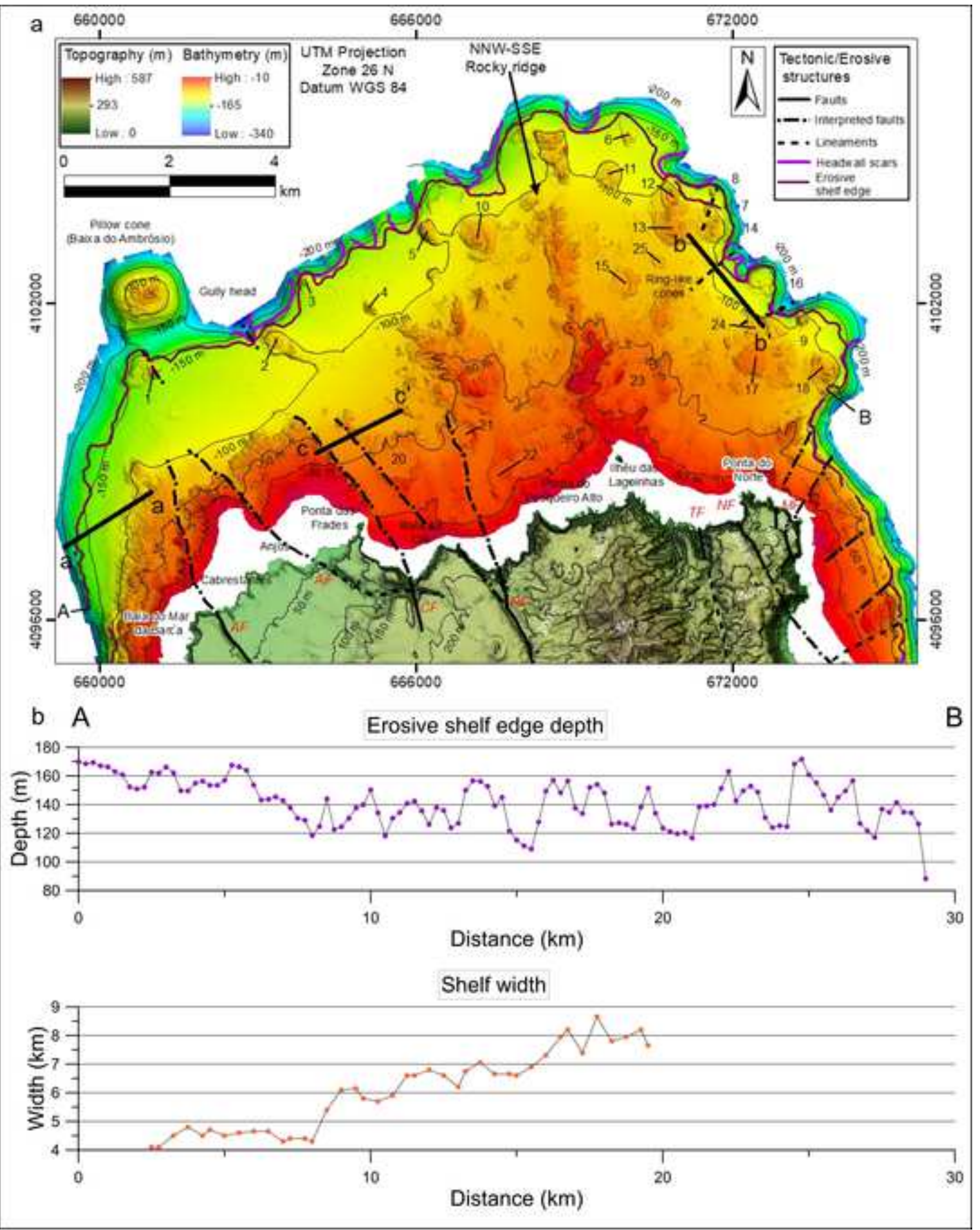




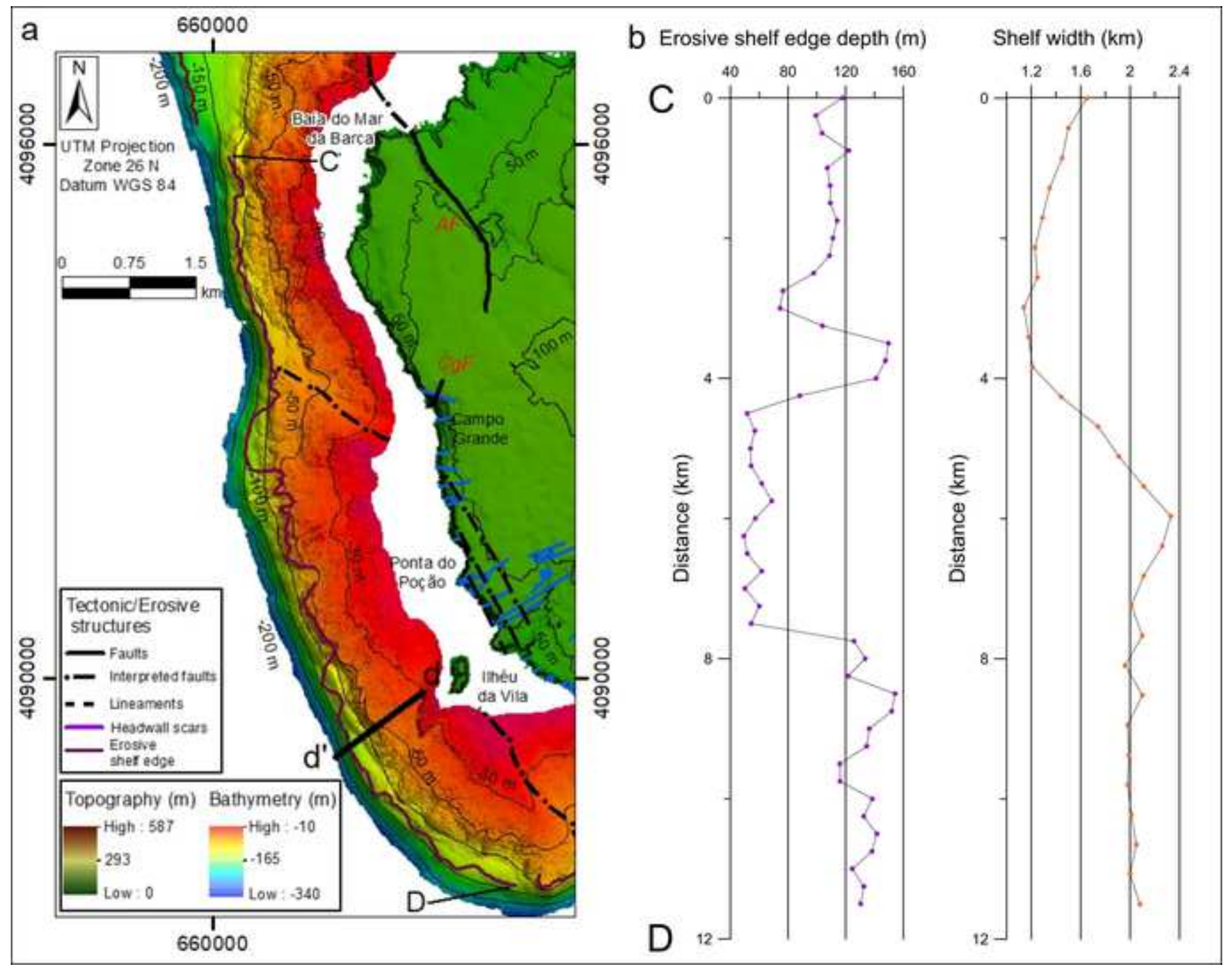




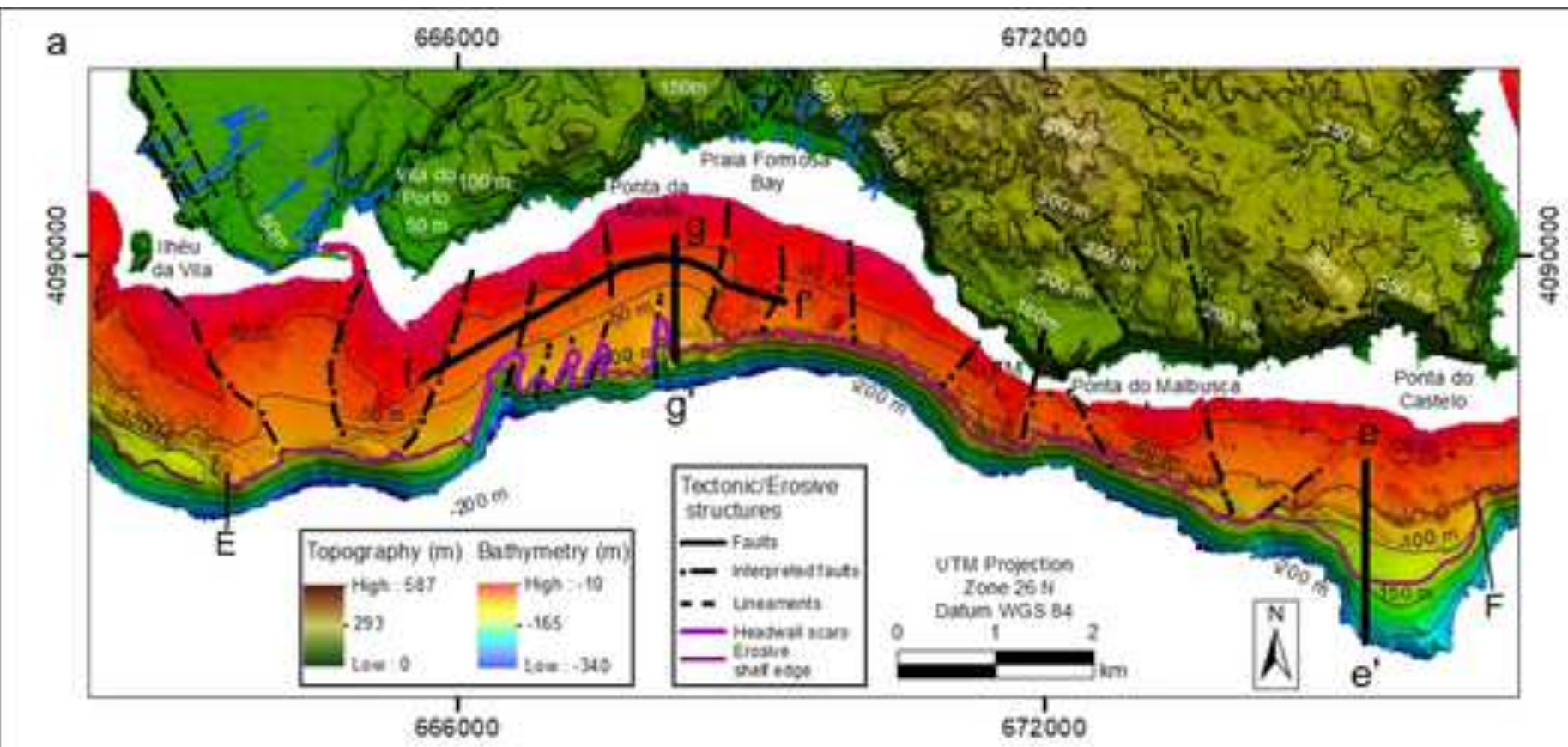

b E

Erosive shelf edge depth

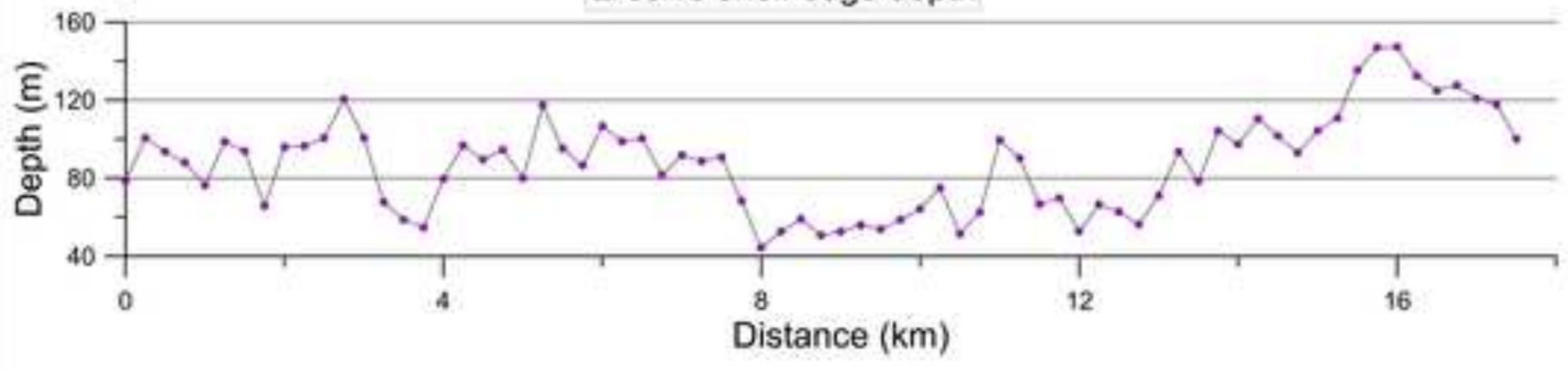

Shelf width

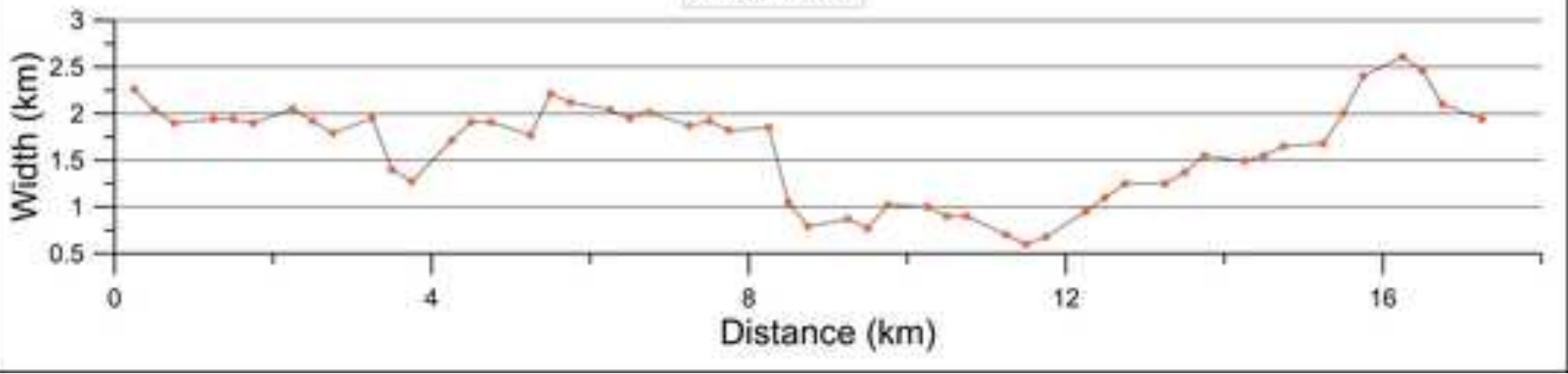




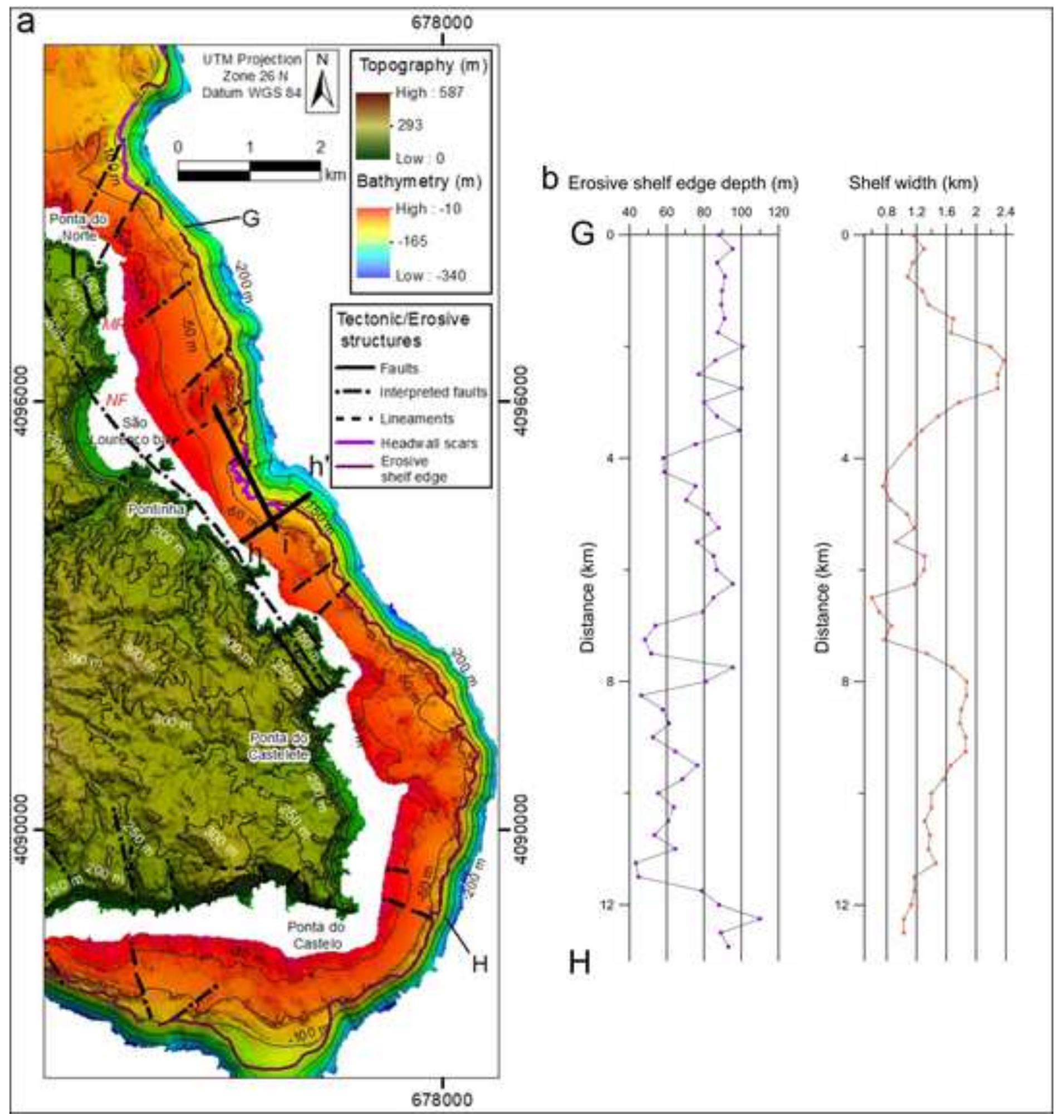




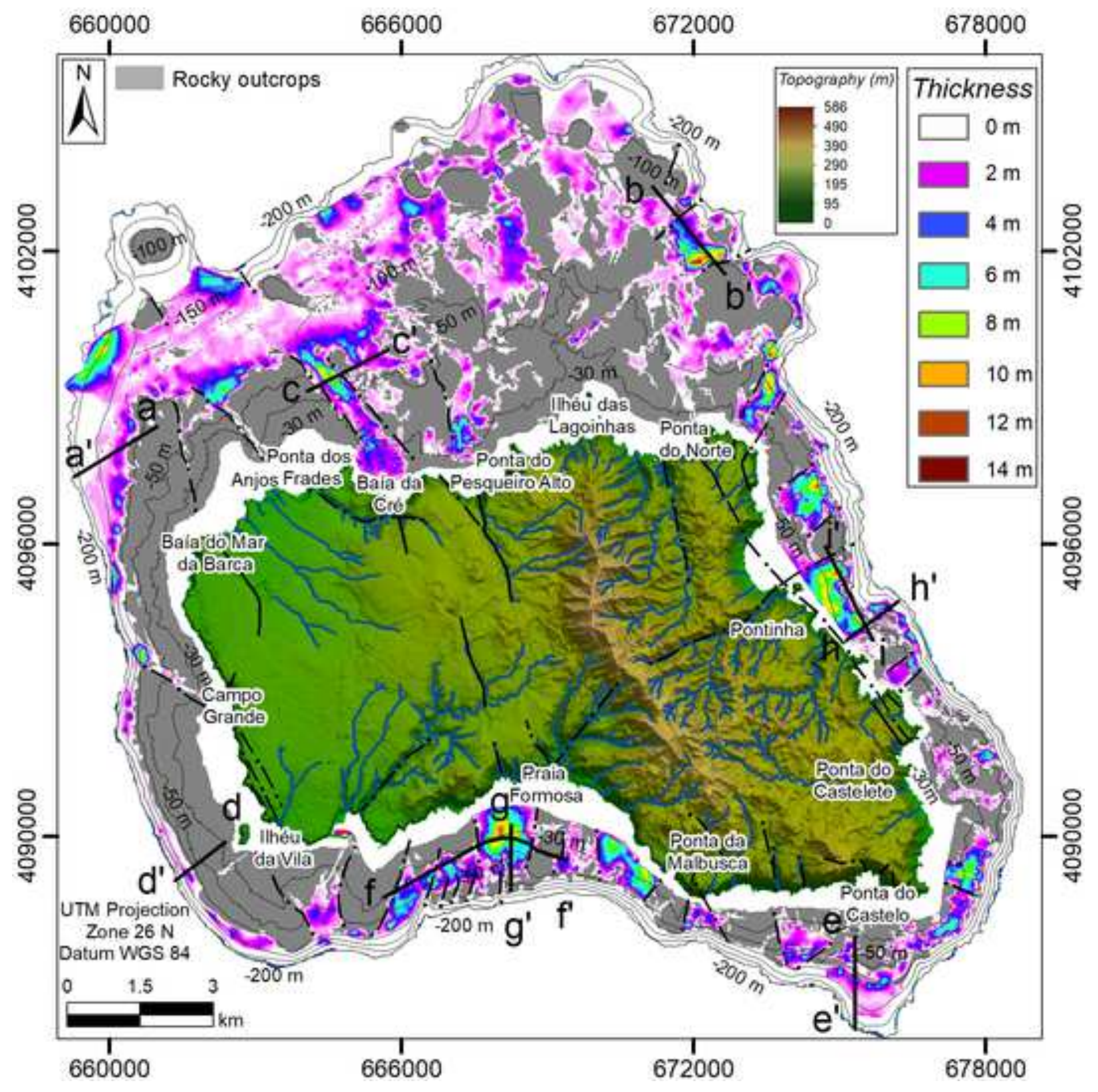




\section{Wave originating direction}

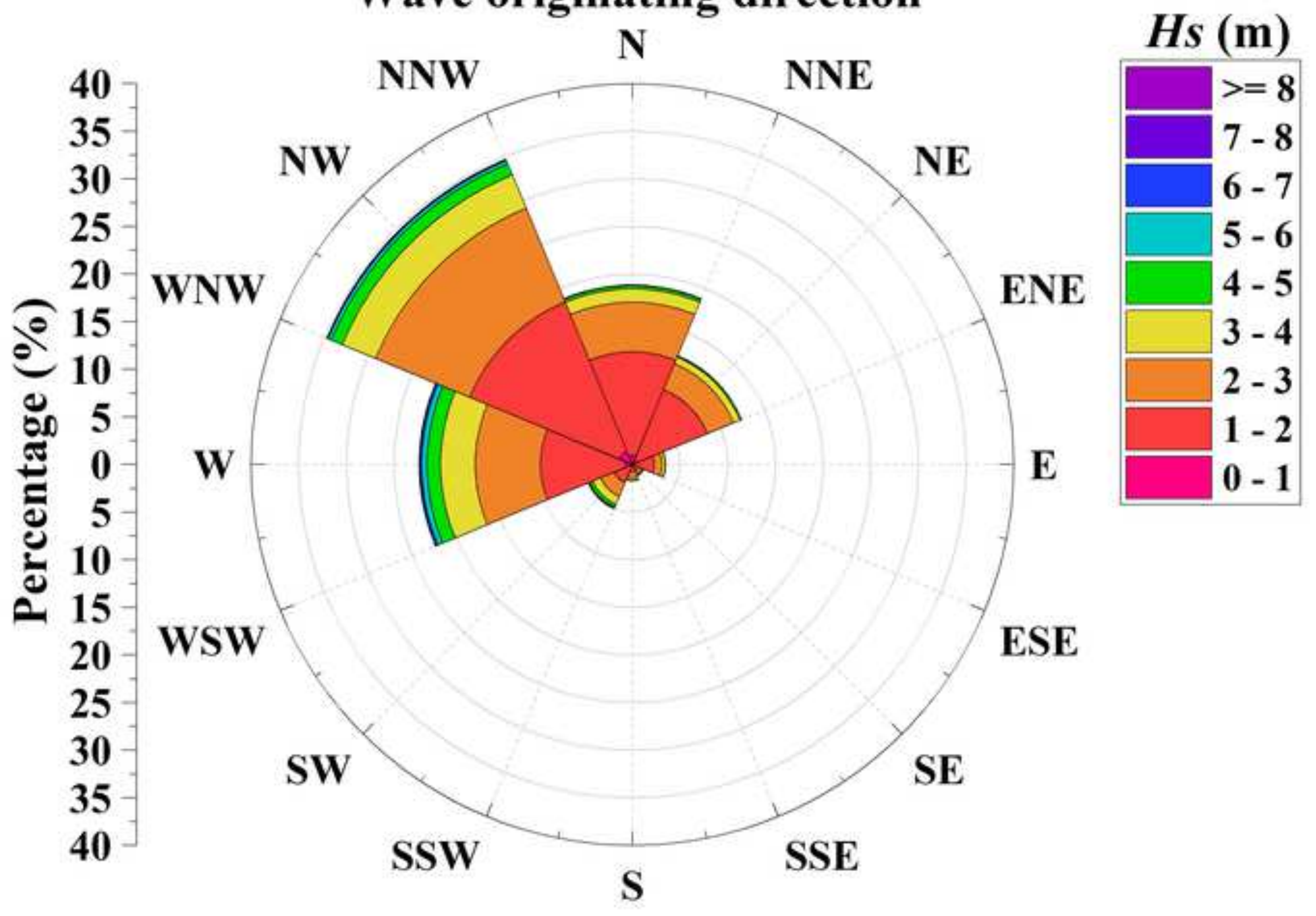




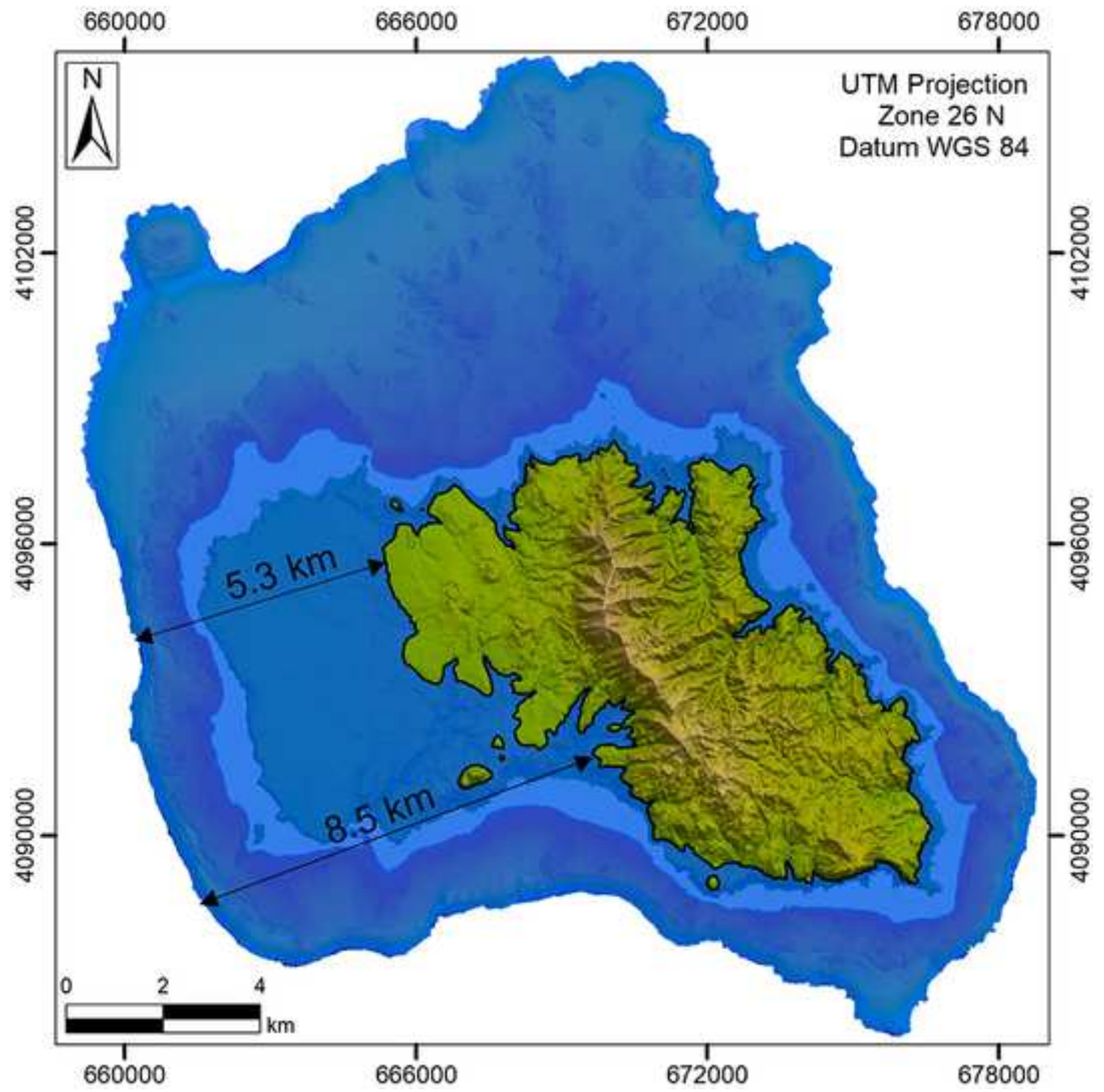




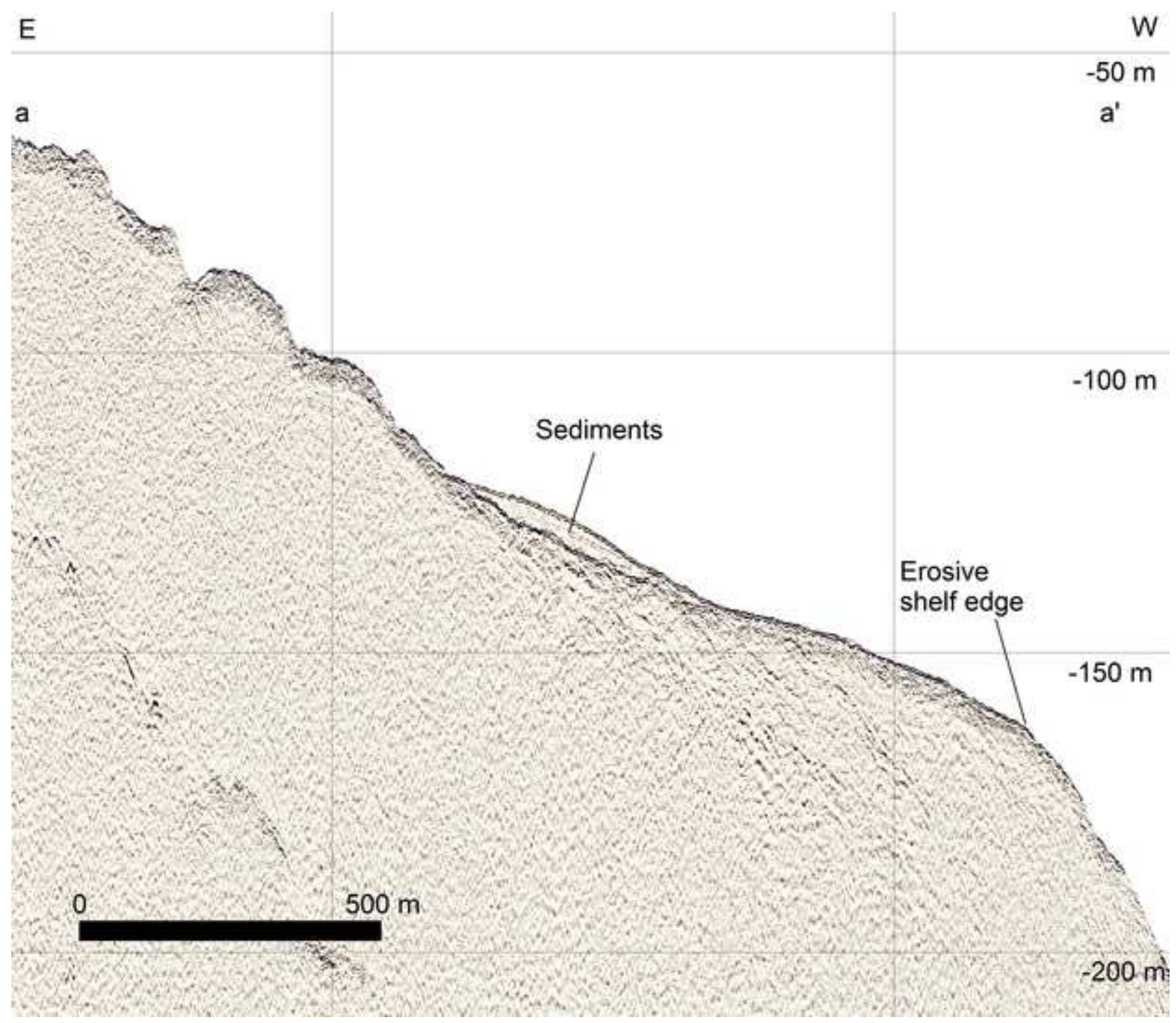




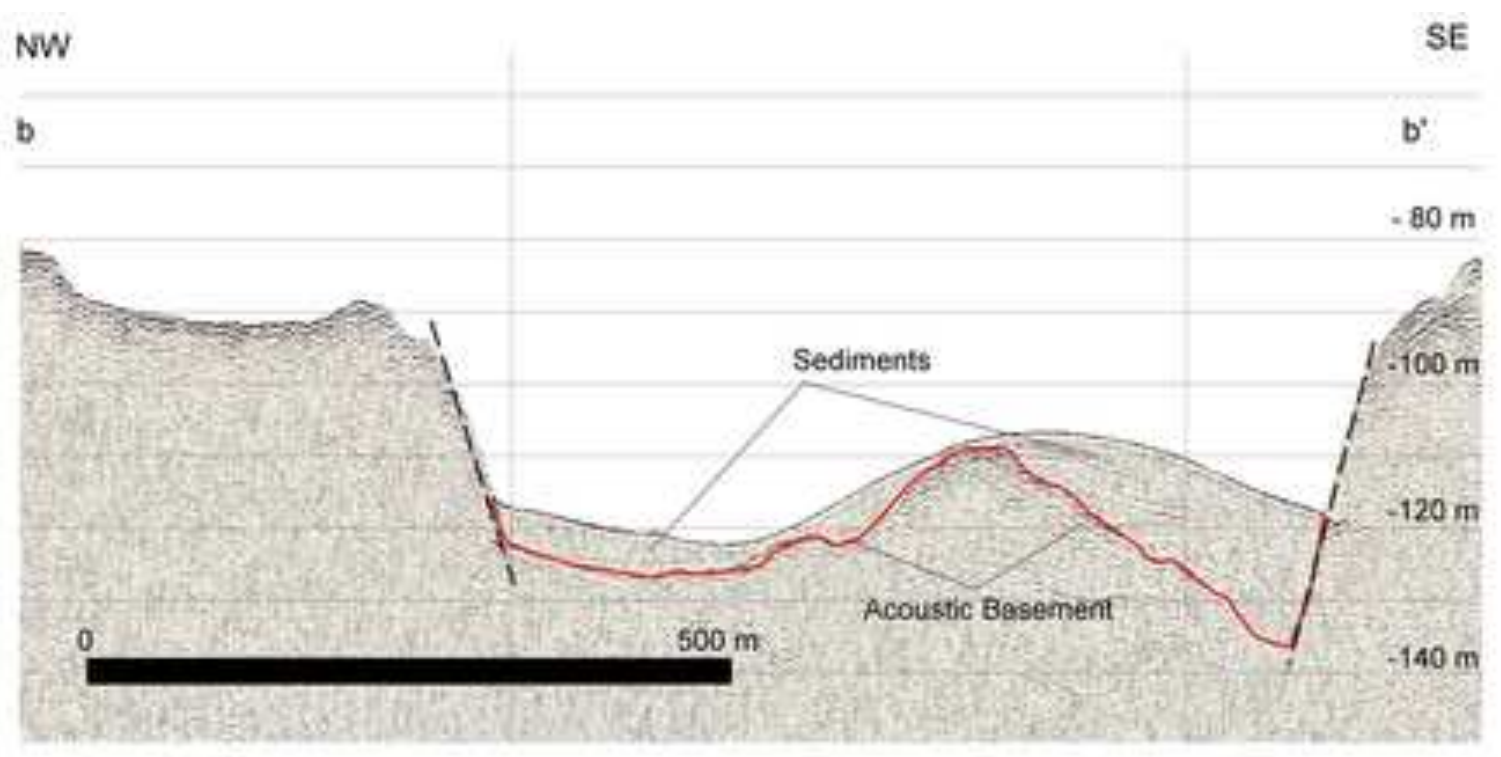

a)

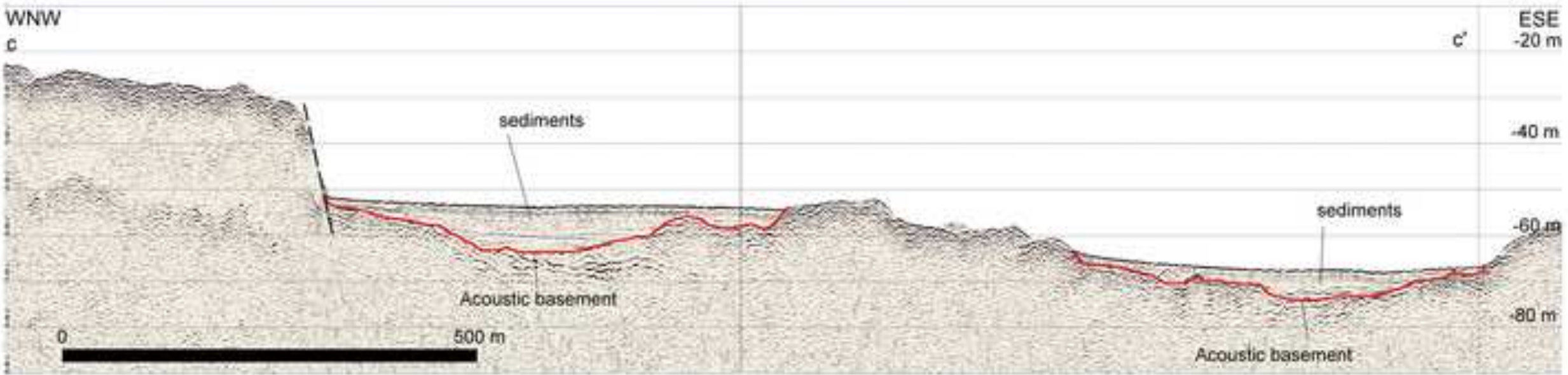




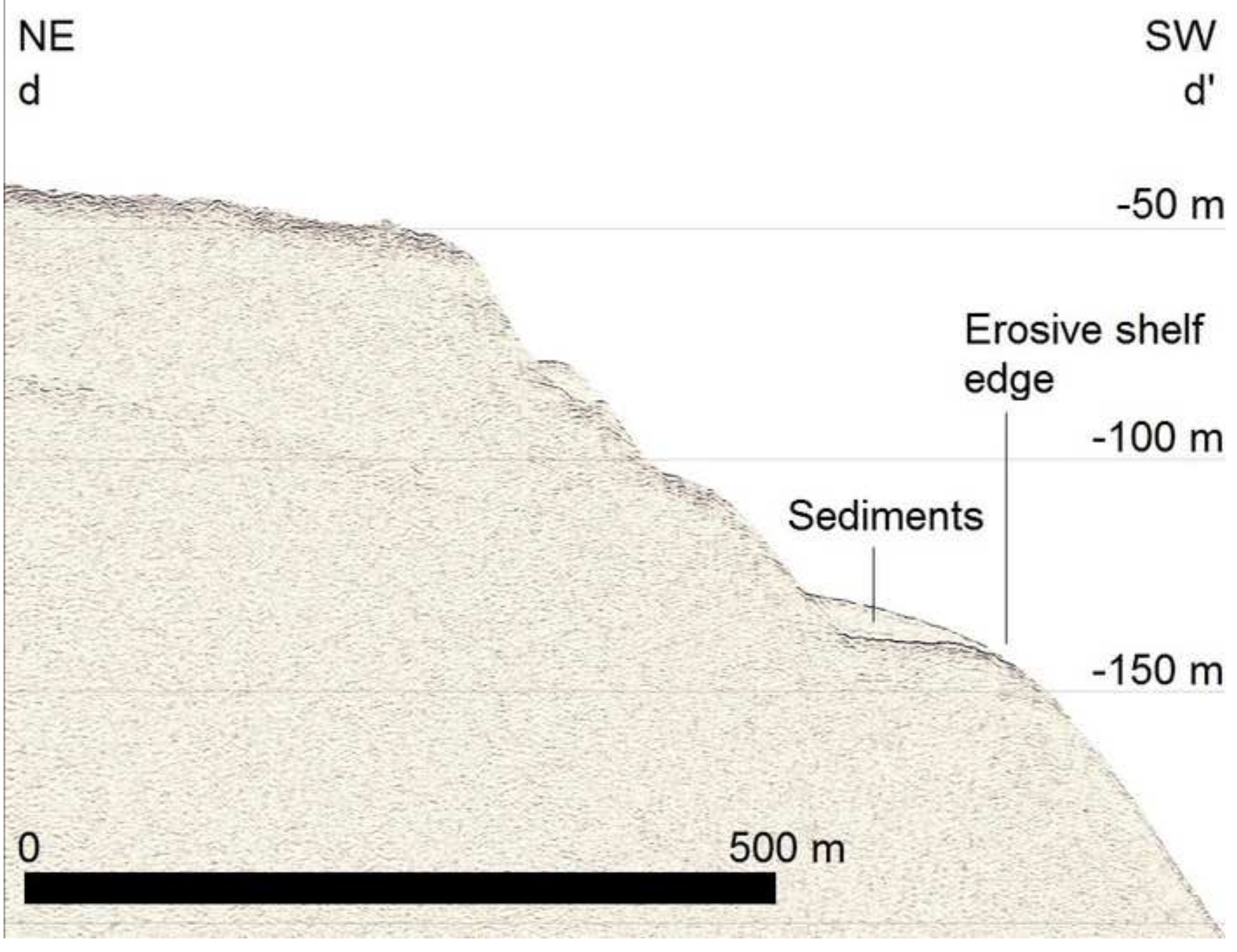




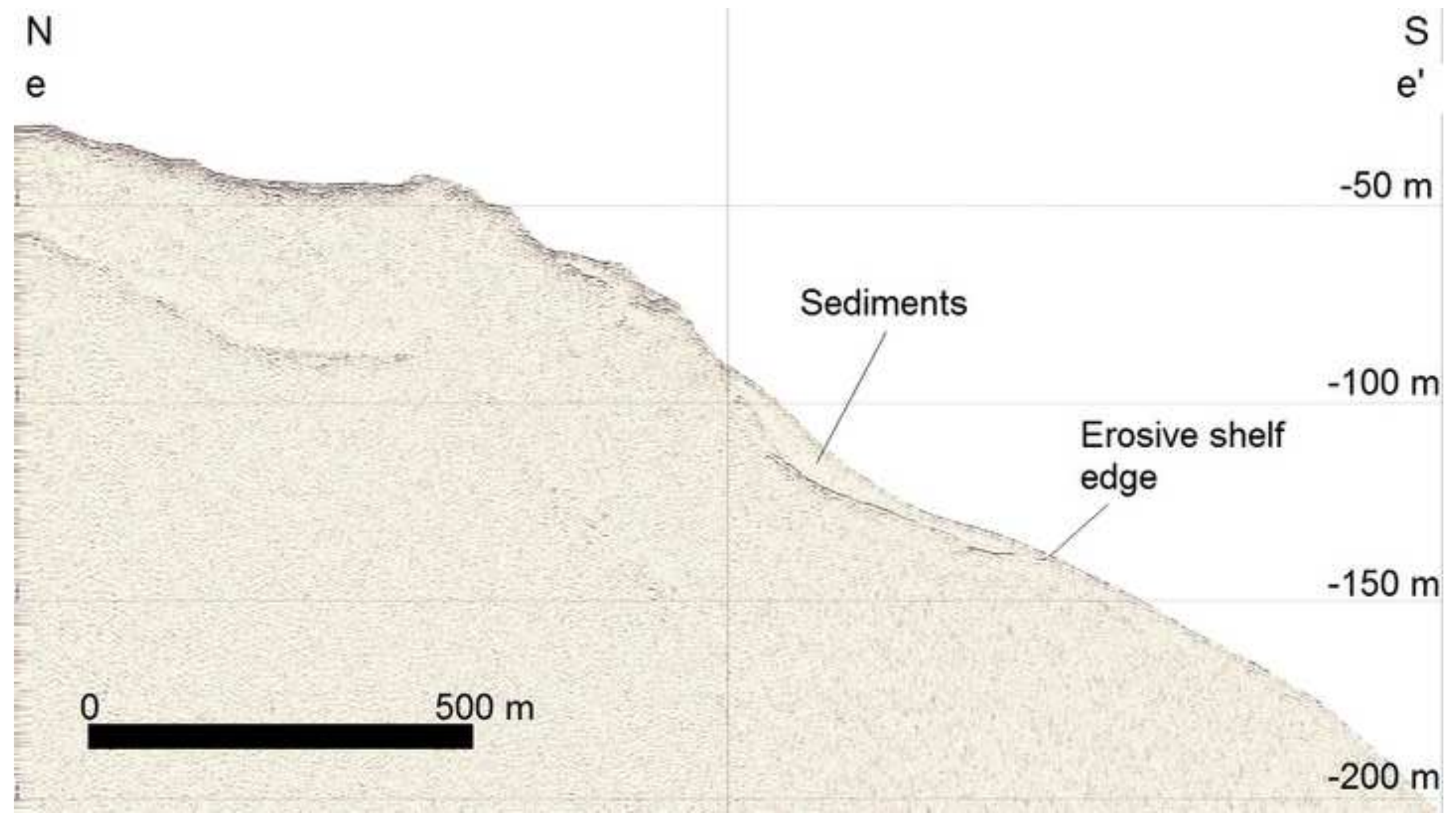




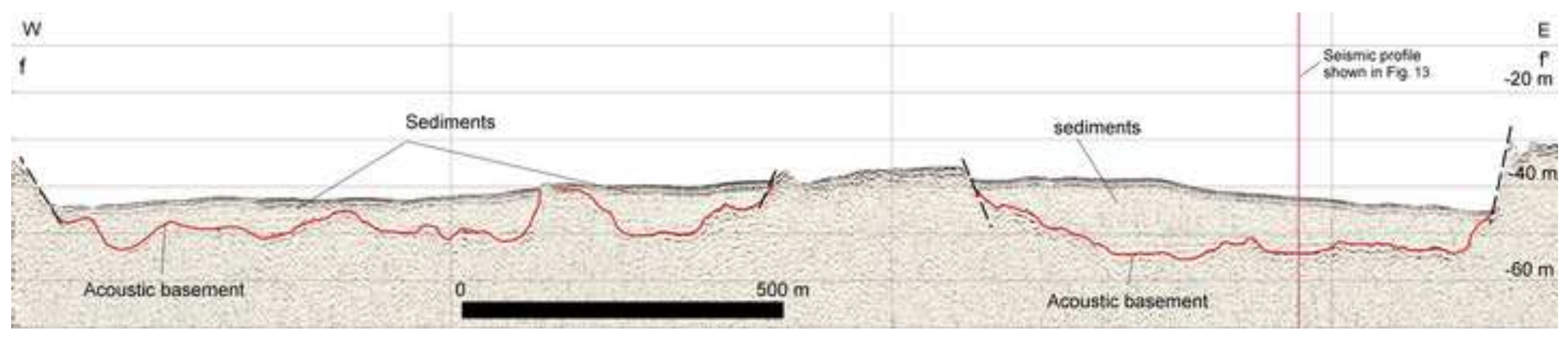




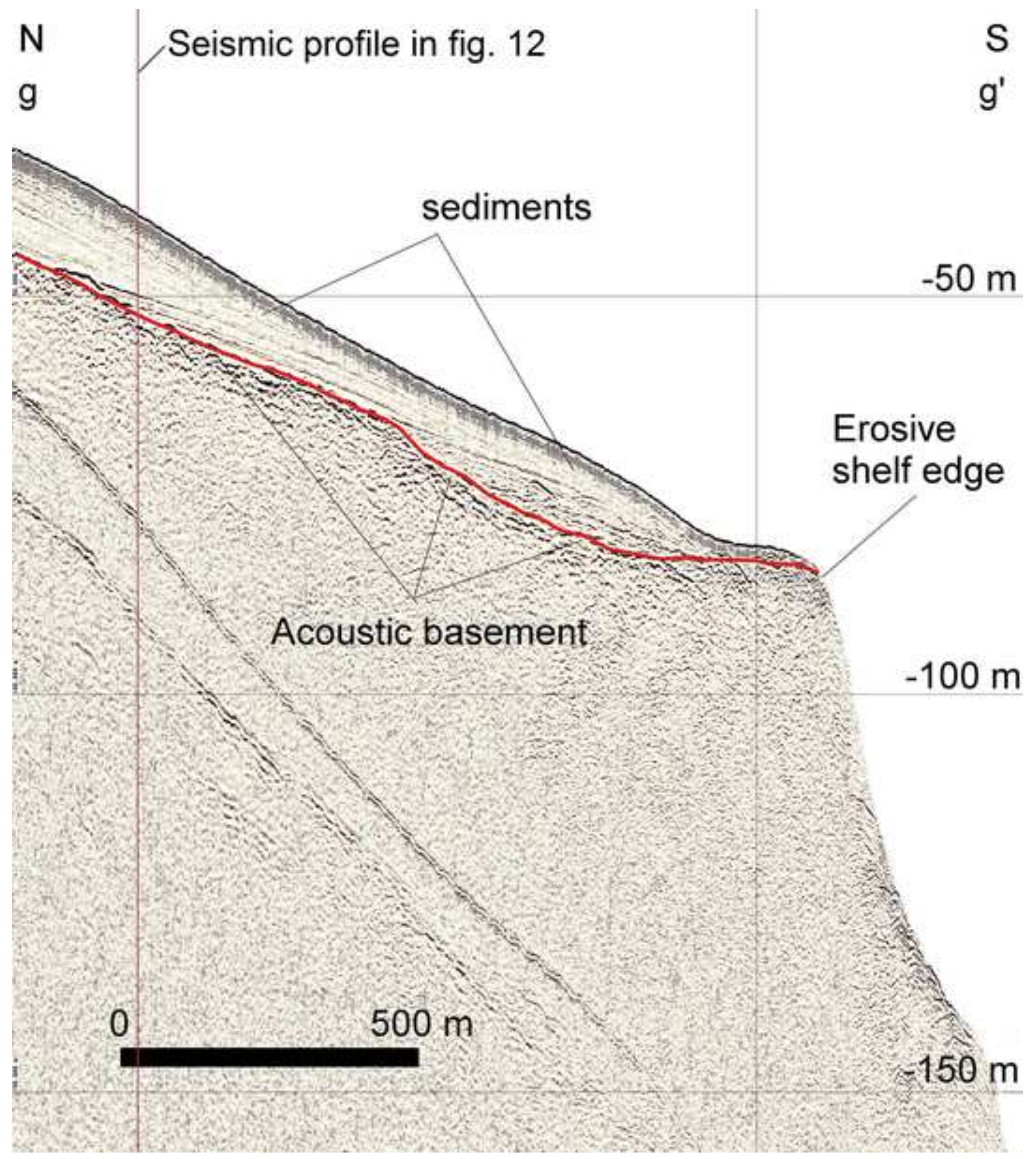




\section{SW}

NE

h

\section{sediments}

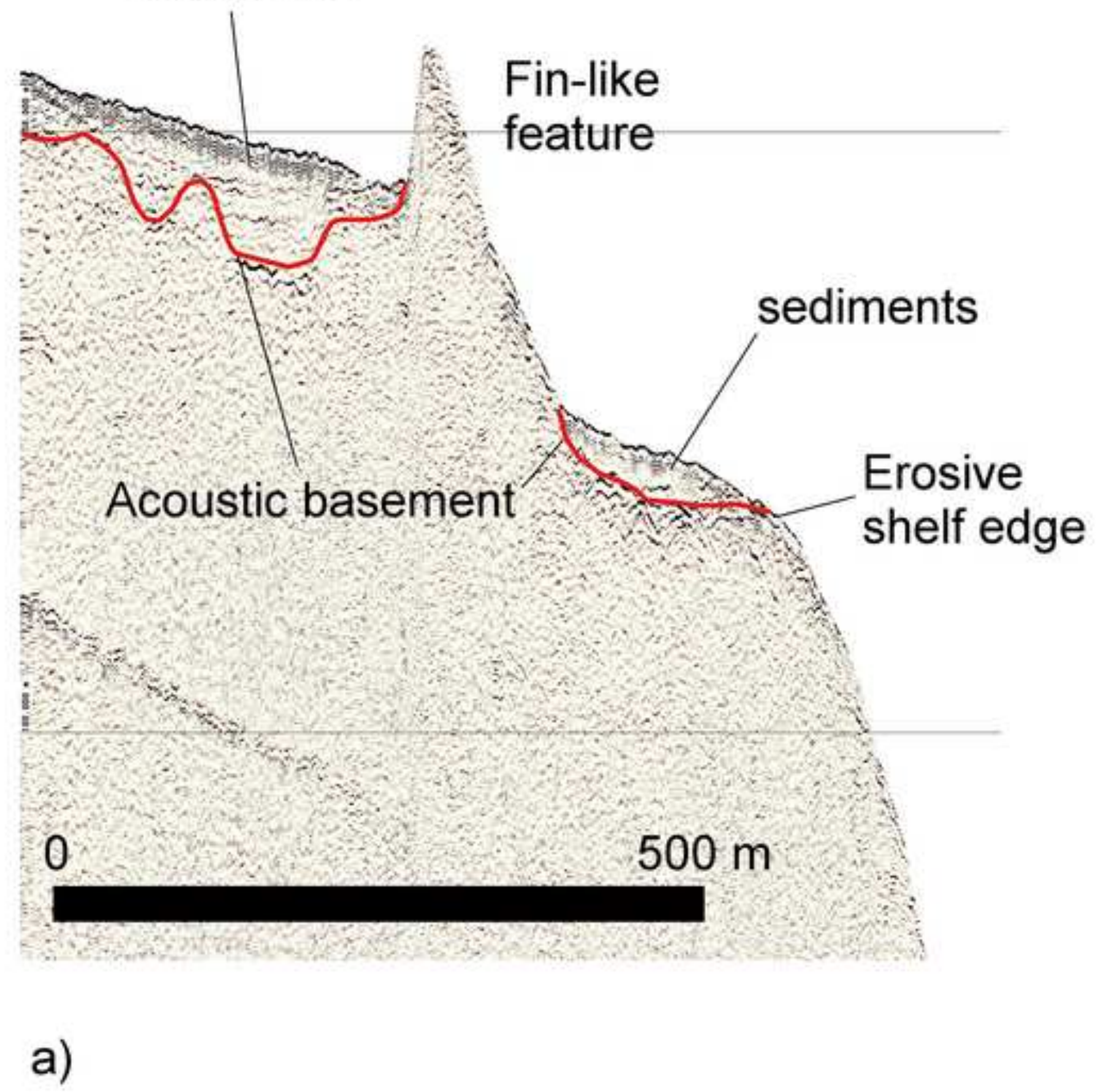

a)

$h^{\prime}$ 


\section{SE}

i

- $1-50 m$

$-100 m$
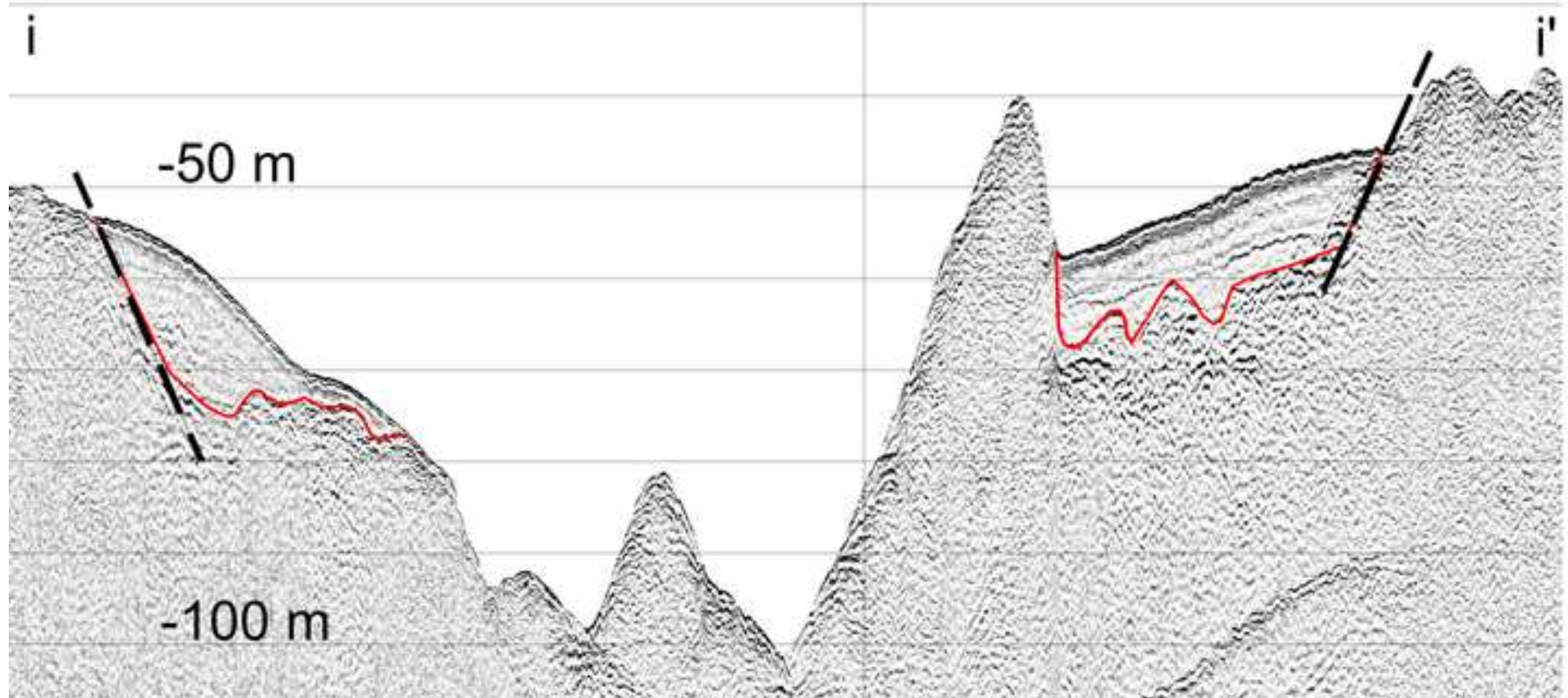

政 